
7

Wei Wei ${ }^{1,3}$, Die Chen ${ }^{1,2}$, Lixin Wang $^{3}$, Stefani Daryanto ${ }^{3}$, Liding Chen ${ }^{1 *}$, Yang $\mathrm{Yu}^{1}$, Yonglong $\mathrm{Lu}^{1}$, Ge Sun ${ }^{4}$, and Tianjiao Feng ${ }^{1,2}$

1. State Key Laboratory of Urban and Regional Ecology, Research Center for Eco-environmental Sciences, Chinese Academy of Sciences, Beijing 100085, China; 2. University of Chinese Academy of Sciences, Beijing 100049, China; 3. Department of Earth Sciences, Indiana University-Purdue University Indianapolis (IUPUI), Indianapolis 46202, United States; 4. Southern Research Station, USDA Forest Service, Raleigh, North Carolina 27606, United States

\title{
Correspondence: Liding@rcees.ac.cn
}

Tel (Fax): +861062913840

Mailing address: No.18, Shuangqing Road, Haidian District, Beijing 100085, China.

8

(9) 
Abstract: For thousands of years, humans have created different types of terraces in different sloping conditions, meant to mitigate flood risks, reduce soil erosion and conserve water. These anthropogenic landscapes can be found in tropical and subtropical rainforests, deserts, arid and semiarid mountains across the globe. Despite the long history, the roles of and the mechanisms by which terracing improves ecosystem services (ES) remain poorly understood. Using literature synthesis and quantitative analysis, the worldwide types, distributions, major benefits and issues of terracing are presented in this review. A key terracing indicator, defined as the ratio of different ES under terraced and non-terraced slopes $(\delta)$, was used to quantify the role of terracing in providing ES. Our results indicated that ES provided by terracing was generally positive because the mean values of $\delta$ were mostly greater than one. The most prominent role of terracing was found in erosion control $(11.46 \pm 2.34)$, followed by runoff reduction $(2.60 \pm 1.79)$, biomass accumulation $(1.94 \pm 0.59)$, soil water recharge $(1.20 \pm 0.23)$, and nutrient enhancement $(1.20 \pm 0.48)$. Terracing, to a lesser extent, could also enhance the survival rates of plant seedlings, promote ecosystem restoration, and increase crop yields. While slopes experiencing severe human disturbance (e.g., overgrazing and deforestation) can generally become more stable after terracing, negative effects of terracing may occur in poorly-designed or poorly-managed terraces. Among the reasons are the lack of environmental legislation, changes in traditional concepts and lifestyles of local people, as well as price decreases for agricultural products. All of these can accelerate terrace abandonment and degradation. In light of these findings, possible solutions regarding socio-economic changes and techniques to improve already degraded terraces are discussed.

Keyword: terracing; ecosystem services; worldwide distribution; land degradation; food security . s. 51

\section{(2)}

\section{3}

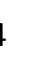

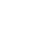
5 


\section{Introduction}

Terraces are considered as one of the most evident anthropogenic imprints on the landscape, covering a considerable part of terrestrial landscapes (Krahtopoulou and Frederick, 2008; Tarolli et al., 2014). Generally, this human-created landscape is more ubiquitous on hill-slopes and other mountainous regions, although it is used extensively across diverse landscapes such as in areas where severe drought, water erosion, mass movement and landslides from steep slopes threaten the security of land productivity, the local environment and human infrastructure (Lasanta et al., 2001). Terraced slopes even became the ideal sites for early human settlement and agricultural activities (Stanchi et al., 2012), with ancient agricultural terraces (e.g., in the central Negev highlands) serve as pronounced evidences of ancient human history, diverse cultures and civilizations (Pietsch and Mabit, 2012; Calderon et al., 2015).

Terracing, referred to as horizontal human-made spaces created to permit or facilitate cultivation on sloping terrains such as on hills and mountains (Petanidou et al., 2008), has been practiced as a key management strategy to minimize climate or human-induced disasters in those fragile landscapes (Chen et al., 2007; Andrew and James, 2011; Li et al., 2014). Since terraces reduce slope steepness by dividing them into short gentle sections (Morgan and Condon; Van Dijk and Bruijnzeel, 2004; Li et al., 2014), they strongly affect soil hydrology, vegetation growth and biogeochemical cycles (Moser et al., 2009). Terracing has been used to conserve water, alleviate flooding risks, reduce erosion, expand high-quality croplands and restore degraded habitats (Van Dijk and Bruijnzeel, 2004; Bruns, 2012). More recently, this practice has been found to improve other ecosystem services (ES), such as carbon sequestration, food security as well as recreation (Ore and Bruins, 2012; Garcia-Franco et al., 2014).

Despite its long history, the fundamental roles and mechanisms of terracing on improving ES and preventing land-degradation remain poorly understood (Frei et al., 2010; Li et al., 2014). At the same time, the specific size, appearance, choice of construction material (i.e., earth, stone or brick), age, land use/vegetation cover, and spatiotemporal distribution of terracing may differ across various ecosystems, resulting in the variability of ES provided by terracing. In other words, the effects of terracing on ecosystems and human welfare can become very complex, particularly 
when different plant species, land uses, topographies, field treatments, and cultures are involved (Hill and Peart, 1998; He et al., 2009). Issues and problems regarding terracing (from design, construction, maintenance cost, to the actual outputs including ES) also remain, highlighting the need for additional research. So far there has been no systematic synthesis regarding worldwide distribution of terracing and associated ES with specific types of terracing. By developing a simple key indicator, utilizing data synthesis from the literature and quantitative analysis approaches, we summarize and discuss the multiple effects of terracing practices on ES and human welfare. The major benefits of terracing to ES are classified and examined, and problems regarding terracing are also discussed, highlighting the major directions for future efforts.

\section{Data Sources and Analytical Methods}

\subsection{Literature review and terrace mapping}

In this study, three key words (i.e., land terracing, terracing, and terrace) were used to search the existing literature from two sources: Web of Science and Google Scholar. The latter served as a supplemental tool to elicit more information. We only recorded research articles that focused on man-made terraces while articles focusing on terraced landscapes formed by non-human forces (e.g., geological terraces) were removed from the database. Therefore, out of 437 articles found during our initial search, we used a final number of 300 publications to generate the geographical distribution of global terrace practice (Figure 1). We specifically selected ancient terraces appeared in the World Heritage List and some other historical terraces recorded in the literature to highlight their significance on human history and to distinguish them from modern terraces (Table $1)$.

\subsection{Data extraction and indicator determination}

Quantitative studies regarding each of our selected ecosystem services (ESs) associated with terracing were based on 300 selected publications. A key indicator $(\delta)$, defined as the ratio of different ESs under terraced and non-terraced slopes, was used to quantify terracing benefits. Non-terraced slopes were considered as controls, and from this point on, they will be referred to as "slopes". A $\delta$ value of 1 (i.e., no difference between terraces and slopes) is used as the threshold to 
distinguish the impact of terracing. If the $\delta$ value is greater than 1 , terracing is considered to play a positive role. On the other hand, if the $\delta$ value is lower than 1 , it is considered that terracing produces a negative impact. Scattered and frequency-distribution diagrams were then generated based on the values of $\delta$ for each ES. Similarly, the causes responsible for negative values were classified and plotted using bar chart and pie mapping methods based on the number of negative reports.

There were four major aspects of ES that were characterized based on the aforementioned key indicator: (i) runoff reduction and water conservation parameters (e.g., runoff depth, runoff coefficient, soil moisture content, water holding capacity), (ii) erosion and sediment yield (e.g., soil loss depth, erosion modulus, sediment yield), (iii) soil nutrient variables (e.g., total N, total K, total $\mathrm{P}$, available $\mathrm{P}$, available $\mathrm{K}, \mathrm{NH}_{4}$, organic matter), and (iv) carbon sequestration, biomass accumulation and agricultural production (e.g., plant survival rates, tree/crop height, DBH, crop yield, crop evapotranspiration, total plant dry matter, plant branch length, number of branches, canopy diameter, aboveground or belowground biomass). While we also recorded soil physical parameters such as bulk density, $\mathrm{pH}$, and porosity as proxies to soil health, we did not differentiate between different types of terraces because many of them play similar roles in providing ecosystem services. All of these data were classified according to each of the above-mentioned ESs and calculated using the following equations to examine the benefits of terracing:

$$
\delta_{r r}=1 /\left[R f_{t} / R f_{s}\right]
$$

where $\delta_{r r}, R f_{t}$, and $R f_{s}$ represent terracing efficiency on runoff reduction, runoff loss under terraces, and runoff loss under slopes, respectively.

$$
\delta_{s w}=S M_{t} / S M_{s}
$$

where $\delta_{s w}, S M_{t}$, and $S M_{s}$ represent terracing efficiency on soil water recharge, soil moisture under terraces and soil moisture under slopes, respectively.

$$
\delta_{s e}=1 /\left[E R_{t} / E R_{s}\right]
$$


where $\delta_{s e}, E R_{t}$, and $E R_{s}$ represent terracing efficiency on erosion and soil loss control, erosion under terraces, and erosion under slopes, respectively.

$$
\delta_{s n}=S N_{t} / S N_{s}
$$

where $\delta_{s n}, S N_{t}$, and $S N_{s}$ represent terracing efficiency on soil nutrients and land productivity, soil nutrients under terraces, and soil nutrients under slopes, respectively.

$$
\delta_{b m}=B M_{t} / B M_{s}
$$

where $\delta_{b m}, B M_{t}$, and $B M_{s}$ represent terracing efficiency on biomass accumulation/crop yield, biomass under terraces, and biomass under slopes, respectively.

\section{Results and Discussion}

\subsection{The historical distribution of terracing}

While the distribution of terraces varied across continents (Figure 1, Table 1), most often terracing practices were found in regions where agricultural civilization firstly developed. The earliest practices of terracing were recorded in Palestine and Yemen about 5000 years ago (Barker et al., 2000). They appeared almost at the same time as the rise of agricultural civilization, and then spread to the drier regions of the Mediterranean (Price and Nixon, 2005; Galletti et al., 2013). While massive terracing practices in the Mediterranean region mainly began from the late $14^{\text {th }}$ century during the Renaissance period in Middle Ages (Nicod, 1990), older terracing practices recorded in the Alpine Region, the Maya Lowlands, the Middle East and sub-Mediterranean areas of Europe, dated back to the Iron Age or even earlier (Dunning and Beach, 1994; Beach et al., 2002; Kuijt et al., 2007; Stanchi et al., 2012). In old England, a terrace was commonly called a "lynch" (lynchet), such as the ancient Lynch Mill (Clark et al., 1967). In Asia, paddy terracing was largely developed in the Yangtze River Basin, spreading later to Southeast Asia (e.g., Philippines, Indonesia, Thailand and Vietnam) more than 5000 years ago (Chang, 1976; Yuan et al., 2014). Some of these practices remain until now, for example, the Hani Terraces (Figure 2c), which are listed as a key pilot of GIAHS (Global Important Agricultural Heritage Systems) and play a key 
role in soil and biodiversity conservation, education, recreation, and aesthetic services.

Insert Figure 1

Insert Table 1

\subsection{Multiple concepts of terracing classification}

Our review indicated that terracing has been and is very diverse in terms of geographical distribution, type, and structure. There are no fixed standards and, as a consequence, terracing largely reflects its specific purpose, the builders' culture and experience, available labor, and economic and political condition. Because the major functions and final services of different terraces may be quite similar, terraces are often built without necessarily following the local climate, geomorphological or social conditions (Cots-Folch et al., 2006; Ramos et al., 2007a).

Insert Figure 2

Insert Table 2

Different classifications of terracing thus exist, based on different viewpoints or interests (Figure 2, Table 2). From the structure and appearance standpoint, terraced landscapes can be classified into wave-like terraces, slope-separated terraces, level-benches, level-ditches, zig terraces, sloping terraces, half-moon terraces (also named fish-scale pits) and broad-base terraces (Sharda et al., 2002, 2013; Liu et al, 2013; Figure 3). Based on the differences in building materials, these terraces can be divided into soil ridge terraces (Fig. $2 \mathrm{~d}$ and e), stone dike terraces (Figure 2f), grass ridge terraces and soil-rock mixed terraces (Abu Hammad et al., 2004). Terraces in the Mediterranean region and South America (e.g., Colombia, Ecuador, Peru and Chile), for example, have mostly been constructed using dry-stone walls (Petanidou et al., 2008; Tarolli et al., 2014). Similar materials for terracing have also been found in China's Yungui Plateau and Three-Gorge Regions (Chen et al., 2007; Li et al., 2014) while terraces in North America, Vietnam, Thailand and NW China are mostly built of soil. According to rainfall availability and climatic zones, terracing generally can be divided into dryland terraces (e.g., Figure 2 d, e, f) and paddy terraces (e.g., Figure 2 a, b, c). Terraces can also be divided into embankment and non-embankment terraces based on the presence or absence of the embankment. Based on the differences in historical value or cultural landscape, they can be divided into ancient terraces (e.g., 

agricultural terraces (Figure 2a, b, c, d), afforestation terraces (e.g., Figure 2e), orchard terraces, tea-garden terraces, mulberry terraces, and rubber terraces based on their purposes (Cots-Folch et al., 2006; Li et al., 2014), which vary greatly across various regions and continents. For instance, terraces in the Asian humid regions are mainly used for rice cultivation, while terraces in Europe are used for grapevines and olive trees. In both of the semi-arid regions (e.g., western Kansas and Nebraska) and humid regions (e.g., Indiana and Kentucky) of North America, parallel terraces, bench terraces, contour terraces and parallel-tile-outlet terraces were mostly used for corn, soybean and wheat cultivation (Wheaton and Monke, 1981). The ancient Incan terraces (known as andenes) in Peru, Bolivia, Chile, Argentina and the South American Andes were once used to cultivate potato and maize, but then suffered from total abandonment about 500 to 700 years ago (Posthumus and Stroosnijder, 2010). Based on the specific location, terraces can also be divided into hillslope terraces and channel terraces. While the majority of terraces were built on hillslopes, in North America (i.e., New Mexico, Colorado Plateau, and Arizona), dry-stone walls related to ancient agricultural terraces were found on channels (Sandor et al., 1990). Similarly in Negev, Israel, due to the extremely dry climate, the ancient agricultural terraces here have existed as thousands of stone-walls in ephemeral stream valleys, where deep loess soil layers and abundant stored runoff-water occurred (Ore and Bruins, 2012).

\subsection{Benefits of terracing}

Incremental slope leveling is considered a normal adjunct to hillside farming, with agricultural practices and environmental constraints being the primary causes of terracing (Williams, 1990). Historically, terracing was regarded as a major adaptive strategy for land use in mountainous and hilly regions (Ramos et al., 2007b) and it performed multiple functions in improving environmental quality (Table 3), including the following ES provisions: (1) runoff reduction and water conservation, (2) control erosion and benefit soil conservation, (3) improve soil fertility and land productivity, (4) increase crop yield and ensure food security, (5) benefit vegetation restoration and enhance biodiversity, and (6) creates aesthetic landscapes and enriches recreational 
options.

\subsubsection{Terracing can boost the efficiency of runoff reduction and water conservation}

221

Our results showed that the mean values of $\delta_{r r}$ and $\delta_{s m}$ were 2.6 and 1.2, respectively (Figures $4 \&$ 5; Table 3), indicating that the efficiency of terraced sites on reducing runoff and conserving soil water (e.g., soil moisture recharge) was greater than that of slopes. Out of the 105 cases extracted from 20 publications, 49 cases had $\delta_{r r}$ values between 1-2, 25 cases had $\delta_{r r}$ between 2-5, and 10 cases had $\delta_{r r}$ greater than 5, only 21 cases were recorded having $\delta_{r r}$ values less than 1 (Figure 4). For $\delta_{s m}$, only 31 cases had a mean value of 0.91 out of total 225 cases, while 189 cases had the $\delta_{s m}$ values between 1 and 2, two cases had $\delta_{s m}$ between 2 and 3, and 3 cases had $\delta_{s m}$ greater than 5 (Figure 5).

There are two major reasons why terracing plays a key role in water conservation. First, terracing can directly reshape hillslope micro-topography and create many micro-watersheds across the whole slopes or within slope channels (Li et al., 2006; He et al., 2009; Courtwright and Findlay, 2011). These alterations can change the specific hydrological pathways and thus greatly increase the concentration, divergence, and efficiency of rainwater harvesting (Bergkamp, 1998; Appels et al., 2011; Adgo et al., 2013; Rockström and Falkenmark, 2015). Terracing in a sub-humid climate and a humid region, for example, was recorded to reduce runoff by $92.6 \%$ and 80\%, respectively, compared to natural slopes (Sharda et al., 2002; Sharda et al., 2013). Second, terracing can increase soil roughness and vertical surface relief, decrease the connectivity of overland flow, which eventually alter raindrop penetration, increase soil moisture and water holding capacity (Díaz et al., 2007; Thompson et al., 2010; Appels et al., 2011). Mean soil moisture could increase from $15.7 \%$ in the slopes to $29.4 \%$ in terraced slopes of the dryland of the Yun-Gui Plateau (Li et al., 2006). Indeed in one study, water holding capacity under terraces could reach 5.0 6.2 times higher than that of slopes (Hu et al., 2007). 


\subsubsection{Terracing can help to control erosion and benefit soil conservation}

Our results suggested that terracing can play a positive role in minimizing erosion and soil loss (Table 3) as indicated by the number of studies with $\delta_{\text {se }}$ value greater than 1 (Figure 6). The mean efficacy of terracing in controlling erosion was 11.46 times higher than that of the control. Out of the 154 available cases drawn from 26 research articles, 79 cases had $\delta_{\text {se }}$ value between 1 and 6, 23 cases had $\delta_{s e}$ between 6 and 10, 24 cases had $\delta_{s e}$ between 10 and 20, and 16 cases had $\delta_{\text {se }}$ greater than 20. In contrast, terraces failed to reduce erosion and soil loss in only 13 cases, with an average $\delta_{s e}$ value of 0.79 (Figure 6). Our results were thus in line with many other studies stressing the benefits of terracing on soil conservation (Nyssen et al., 2004; Hu et al., 2007; Hallema and Moussa, 2014; Zhang and Li, 2014). An appreciable erosion reduction could be achieved if terraces covered over $40 \%$ of the total hillslope (Al Ali et al., 2008). Other studies even reported that terracing could reduce over $90 \%$ of total soil loss (He et al., 2009; Zhang et al., 2010). Studies in Thailand and the Czech Republic indicated that terracing could markedly increase soil conservation provided that weed cover and furrow management were also available (Sang-Arun et al., 2006; Dumbrovsky et al., 2014). Montgomery (2007) found rice terracing systems produced very low erosion rates $\left(<10^{-4}\right.$ to $0.01 \mathrm{~mm} / \mathrm{yr}$, close to geological erosion rates), while other agricultural practices (e.g., conventional tillage) produced far higher erosion rates $(0.1$ to $>10$ $\mathrm{mm} / \mathrm{yr}$ ), inducing unsustainable consequences on soil resources.

The reasons why terracing can control erosion are straightforward. First, terracing can markedly weaken rainfall-runoff erosivity (Chen et al., 2012) by reducing the velocity and total amount of overland flow (Section 3.3.1). Second, terracing can conserve abundant rainwater and increase soil moisture availability as well as nutrients and land productivity (which will be discussed in the next section), benefiting plant growth and increasing canopy coverage. Increasing biomass and surface cover significantly decrease raindrop energy, creating a positive feedback by reducing splash, rill, and inter-rill erosion (Zhang and Cao, 2008). Third, terracing often has specific measures (e.g., ridges or embankments), which contributes greatly to soil conservation. Terraces with embankments mainly generated tillage erosion (accounting for $65 \%-71 \%$ of the total erosion), 
with a minor degree of water erosion (Zhang and $\mathrm{Li}$ 2014). In contrast, terracing without embankments in tilled soils generated both severe tillage erosion and water erosion, inducing more substantial soil loss. In the dryland loess area of China, for example, terraces with ridges could conserve all of the runoff and sediment, while terraces without ridges only conserved $82 \%$ overland flow and 95\% sediment, respectively (Jiao and Wang, 1999).

\section{Insert Figure 6}

\subsubsection{Terracing can improve soil fertility and land productivity}

Our results showed that in most cases, terracing could improve soil nutrient flux, although a few negative reports were also found (i.e., 18 out of 108 cases) (Figure 7). The remaining 89 cases had $\delta_{s n}$ values between 1 and 2, two cases had $\delta_{s n}$ between 2 and 3, with mean $\delta_{s n}$ values of 1.23 and 2.47, respectively (Table 3 and Figure 7). As most nutrients are dissolved in water or attached to soil particles, terracing can directly improve soil nutrient status by minimizing water erosion, particularly when barren slope practice is coupled with irrigation and fertilizer (Ramos et al., 2007; Wen, 2009; Shimeles et al., 2012). Compared with barren slopes, available P/K, total N, and soil organic matter in the first $0-60 \mathrm{~cm}$ soil layers under level ditches, zig terraces and half-moon terraces increased by up to $30 \%, 28.1 \%$ and $41.7 \%$, respectively (Hu et al., 2007; Zhang and Cao, 2008). Terracing with supplemental treatments (e.g., terraced orchards with grass cover and contour hedgerows), rather than sloping orchards, could markedly improve hydraulic conductivity, aggregate soil stability, soil organic matter and available N, P, K, while decreasing soil bulk density (Xu et al., 2012). With fertilizer and plant litter inputs and root recycling, long-term cultivation and field managements from ancient terraces were found to accelerate soil genesis and accumulate more nutrients (Homburg and Sandor, 2011).

\section{Insert Figure 7}

\subsubsection{Terracing can increase crop yield and ensure food security}

Terrace farming has long been considered an ancient indigenous model to ensure food security (Wheaton and Monke, 1981; Williams, 1990). It can increase crop yield and help to fight famine, particularly when water scarcity and soil erosion become the main concerns in many mountainous 
regions (Rockström and Falkenmark, 2015). Terracing can mitigate drought by facilitating soil moisture conservation (Figure 5) and accumulating nutrients for crops (Figure 7), thus increasing their production potential (Figure 8). A more favorable interaction between water and fertilizer also can occur with terracing since soil water retention improved under terracing (Liu et al., 2011). Average crop yields on terraced teff (Eragros ticabyssinica L.), barley (Hordeum vulgare L.) and maize (Zea mays L.) in China and Palestinian fields were at least two-times greater than that on slopes (Liu et al., 2011; Hammad and Børresen, 2006).

Compared with slopes, the net benefits of crop yields on terraced fields were also greater (Adgo et al., 2013). The yields of maize and wheat under terraces could increase 3-4 times and 6-7 times than when grown on slopes, respectively, under same input costs (Wickama et al., 2014; Abu Hammad and Børresen, 2006). In Peru, 2 to 4-year old bench terraces resulted in $20 \%$ greater yields than adjacent sloping fields (Posthumus and Stroosnijder, 2010), potentially increasing per capita incomes by up to $15 \%$ and reducing poverty by $9 \%$ (Antle et al., 2007). Cultivated bench terrace systems, rather than conventional systems (i.e., sloping cultivation), were more effective in improving land productivity by over $19 \%$ in terms of maize-equivalent yields (Sharda et al., 2002). In Africa, terracing combined with other conservation means (e.g., grass strips) has been implemented extensively to control land degradation and improve crop productivity (Adgo et al., 2013).

\subsubsection{Terracing can benefit vegetation restoration and enhance biodiversity}

In many degraded or water-limited ecosystems, the success of an afforestation or reforestation program will be difficult to achieve without other vital measures because of poor existing site conditions and a harsh climate (Wang et al., 2011; Groninger, 2012). Terracing, as an additional measure or approach, can play a key role in re-constructing and improving habitats, thus benefiting ecosystem restoration and enhancing biodiversity (Wei et al., 2012; Armitage et al., 2014). Several points help to understand the roles of terracing in improving vegetation survival.

First, terracing can decrease the mortality of plant seedlings, particularly in regions where rainfall is scarce. In Northern China, for example, the survival values for locust trees (Robinia 
pseudoacacia L.) were recorded at $89.5 \%, 81.3 \%, 75.6 \%$ in broad-base terraces, level ditches, half-moon terraces, respectively, compared to only $34.7 \%$ on slopes (Hu et al., 2007; Zhu and Fang, 2009). Second, plant growth can be improved by terracing as water and nutrients become more available. Compared to slopes, mean stem diameter, branch length, branch number and leaf yields per plant of mulberry trees (Fructus mori) grown on zig terraces versus on slopes by $120 \%$, 125\%, 175\% and 240\%, respectively (Zhang and Cao, 2008). Compared to controlled sites, terraced fields had greater plant growth through rainwater interception and site improvements in Spain, China, and Afghanistan (Yang and Ma, 2004; Zhao and Cai, 2012; Shi et al., 2013; Garcia-Franco et al., 2014). Third, terracing may help to increase the diversity of plant species by improving the growing conditions for different species. In Japan, the diversity of weed species in stone-walled terraces was recorded to be higher than that in sloping forests (Tokuoka and Hashigoe, 2015).

\subsubsection{Terracing creates aesthetic landscapes and enriches recreational options}

Extensive terracing projects have markedly re-shaped landscapes, increasing their geo-diversity (Hobbs et al., 2014) and attracting thousands of visitors each year. Many terraces were even identified as "cultural landscape" heritages, expressing harmony between humans and the environment (UNESCO, 2008). Cultural landscapes, defined as "distinctive geographical areas or unique properties that represent the combined work of nature and of man" by the World Heritage Committee, play crucial roles in aesthetic appreciation, recreational and spiritual enrichment (UNESCO, 2008; Figure 1; Table 1). There are over tens of famous terraced landscapes in China and many other countries chosen by public appraisals (Table 1; Hill and Peart, 1998; Lu and Stocking, 2000; Sun et al., 2013), which are highly praised as productive, harmonious, clean, and sustainable landscapes (Paoletti, 1999). Some of them (e.g., the terraced agricultural landscape created by Hani ethnic groups) have even been declared as an UNESCO World Heritage site. All these terraced landscapes contribute ecosystem services including cultural and spiritual values (UNESCO, 2008).

\subsection{Issues of terracing: facing the challenges}

Although the majority of collected terracing cases resulted in positive outcomes, there were 
negative cases (Figure 9), partly due to the diversity of terracing types and histories, socioeconomic factors, techniques and knowledge levels, personal concepts and ideas as well as interactions of these factors. Our analysis from 60 negative reports on terracing suggested that there were at least four major reasons contributing to terrace failures in providing ES (Posthumus and Graaff, 2005; Sang-Arun et al., 2006; Tarolli et al., 2014; Figure 10) and these were (1) terrace abandonment, (2) inappropriate management of terraces, (3) lack of appropriate regulations regarding the design of terraces, and (4) the insufficient transfer of knowledge regarding terrace construction.

\section{Insert Figure 9}

Insert Figure 10

\subsubsection{Terrace abandonment}

Based on our literature search and analysis, one of the key issues associated with terracing is their abandonment, accounting for about $49 \%$ of terrace failures (Figure 10). Such abandonments generally equal to a total lack of maintenance, which in the long run can accelerate the formation of existed rills, interrills, gullies, gravitational erosion, piping and landslides on marginal slopes (Lasanta et al., 2001; Koulouri and Giourga, 2007; Garcia-Ruiz et al., 2013). Without adequate maintenance, various natural or other human-generated forces will gradually damage the structure and strength of terrace walls and risers, leading to a complete terrace failure. In Northern China, at least $40 \%$ of the Dazhai Terraces constructed in the late 1960s were damaged due to long-term degradation and poor management (Peng and Zhang, 2005). In the Mediterranean regions, over 50\% of abandoned terraces were vulnerable to gully erosion and landslides, causing collapse of the dry-stone terrace walls (Lesschen et al., 2008; Bellin et al., 2009). Once collapsed, the reconstruction costs will be very high, which exacerbates the status of terracing and eventually leads to more severe land degradation.

There are multiple drivers of terrace abandonments. One of the most common reasons is the absence of labor and a rural population where those terraces exist. Poverty as well as changes in the traditional values and lifestyle of rural communities (Posthumus and Graaff, 2005) result in the 
majority of young residents leaving their own land and migrating to big cities where economic and work conditions are perceived superior (Lasanta et al., 2001; Tarolli et al., 2014), leaving behind old farmers (Garcia-Ruiz et al., 2013; Qiu et al., 2014). Meanwhile, slumps in agriculture prices and high maintenance costs reduce the economic returns of terracing (Antle et al., 2007; José et al., 2013; Qiu et al., 2014). As terracing costs increased with increasing slope gradients (Table 4), terrace profitability decreased faster than once believed by farmers and stakeholders as indicated by a cost-benefit analysis from 11 cases in Peru (Posthumus and Graaff, 2005; Bizoza and Graaff, 2012). Limited accessibility (e.g., poor road condition, steep topography and remote marginal areas) of some terraces also contributed to the large-scale abandonment of old terraced olive orchards in Europe, inducing a productivity decline and thus economic losses (Duarte et al., 2008).

Insert Table 4

\subsubsection{The inappropriate management of terraces}

Inappropriate terrace management was the second major reason of terrace failures, contributing to about $20 \%$ of the reported terrace failures (Figure 10). In upland Java, there was about 2.8-times greater runoff from the riser than from the terrace beds (Purwanto and Bruijnzeel, 1998; Van Dijk and Bruijnzeel, 2004). Better management should therefore focus on the more fragile and sensitive parts of the terraces (e.g., risers and bunds) as the intensity of erosion on terrace risers is often greater than that on terrace beds. Additional treatments such as mulching and vegetation cover are often necessary to protect the risers and bunds as degraded earth bunds and barren risers often became significant sediment sources (e.g., in the Mediterranean regions) (Bellin et al., 2009). As another example, stone terraces in Ethiopia that were not protected by effective vegetation cover led to widespread land degradation and water erosion (Taddese, 2001).

\subsubsection{The lack of appropriate regulations regarding the design of terraces}

Our analysis suggested that poor-quality terracing design ranked third (18\%) among the reasons of terrace failures (Figure 10). Evidence indicates that the ratio between riser gradient and height is important in determining the strength and durability of a terrace (Díaz et al., 2007). Yet many 
terraces (with some exceptions such as the one in the Negev highland; Ore and Bruins, 2012) did not take advantage of this knowledge, inducing unstable terraced slopes. So far, subjective factors (e.g., the ease to run agricultural machinery, field size, bund height, and the locations of outlet within the bund) largely determined terrace structure (Chen et al., 2014), making some terraces prone to severe failures (Ramos and Porta, 1997). Local farmers or their contractors often randomly determine the height and outlet location of paddy terraces in many Asian countries (Chen et al., 2014). The absence of environmental legislation on terracing (Cots-Folch et al., 2006) further exacerbates the risks of terrace failure, even for modern terraces. Poorly-structured terraces of the Priorat vineyards in Spain, for example, was recorded to induce severe landslides affected by only a single rainstorm, causing substantial damage to plants and drainage systems (Ramos et al., 2007b). Stone terraces in Guangxi of China were also developed with a much higher riser than those built from soils, trapping thick sediments and raising the risks of gravitational erosion and slope failure (McConchie and Ma, 2002).

\subsubsection{The insufficient transfer of knowledge regarding terrace construction}

Currently, detailed knowledge and skills on how to better protect the existing terraces or on how to develop well-designed terraces are still lacking, particularly at the farmer-level. These may include but is not limited to the lack of knowledge transfer from academia and policymakers to farmers. When knowledge is not transferred or is poorly transferred, misunderstandings are created. When bench terraces needed to be covered by weed to reduce erosion, the majority of farmers (over 70\%) in Northern Thailand had no willingness to grow weeds in their farmlands due to concern about potential nutrient competition (Sang-Arun et al., 2006). Yet rill erosion, which could develop into gullies running from the upper to the lower terraces, was very common on bare bench terraces in this region (Sang-Arun et al., 2006).

Other factors, such as the specific land use and external field choices, may also add to the complexity of terracing knowledge. For example, erosion rates declined sharply from 4.15 ton $\mathrm{ha}^{-1} \mathrm{yr}^{-1}$ to 0.77 ton $\mathrm{ha}^{-1} \mathrm{yr}^{-1}$ when land use in the same terraced sites was transformed from green manure into rice (Chen et al., 2012). Adding trenches in Indian paddy terraces could increase soil 
moisture and productivity by 58\%-64\% (Kumar et al., 2014). The cutting sections of new terraces reduce crop yields as a result of the removal of fertile soil and the compaction of the remaining soil. Understanding these outcomes, by the appropriate transfer of knowledge, to farmers may assist them in taking measures (e.g., soil backfill and loosening) to avoid unnecessary economic losses (Liu et al., 2008; Blécourt et al., 2014). One particularly effective way to transfer knowledge is to use one farmer, who already is using the transferred knowledge, to demonstrate the approach and its advantages to other nearby farmers.

\section{Concluding remarks and suggestions}

Our global synthesis suggested that diverse terracing practices played a positive role in ES provisions, particularly erosion control, followed by runoff reduction, biomass accumulation, soil water recharge, and nutrient enhancement. Despite their importance, terracing failures still occur in many regions, resulting from agricultural abandonment, the lack of an appropriate design, environmental legislation, and the insufficient knowledge regarding design, construction and maintenance alternatives. More importantly, changes in the traditional concept and lifestyle, as well as price slumps of agricultural products have caused severe losses of local labor, which directly resulted in induced widespread terrace abandonment.

In light of these results, we make several recommendations to better manage terracing practices. First, the scientific criteria for terracing designs should be developed, including the associated environmental legislations. Here it is important to understand that no one design criteria will meet all of the climate, crop, cultural and geographic opportunities and constraints. Second, terraces need to be built in conjunction with other water recycling techniques and field treatments such as vegetation cover and riser protection, to ensure the security of terraces, the efficiency of rainwater harvesting and land productivity. Lastly, there is an urgent need to transfer knowledge from academia or policy makers to local farmers regarding terracing and sustainable land management. The potential damage and risks of agricultural terraces should be better evaluated to protect both the farmer and the greater watershed interests. Special funds and economic subsidies regarding terracing should be considered in order to achieve better management from farmers, which may help with the goals of environmental protection and land sustainability. 


\section{Acknowledgements}

This research was supported by the National Natural Science Foundation of China (41371123; 41390462), and the Innovation Project of the State Key Laboratory of Urban and Regional Ecology of China (SKLURE2013-1-02). Our sincere thanks to Dr. Tom Hinckley, the editor Dr. Joan Florsheim, as well as the anonymous reviewers for their constructive comments and kind assistance.

\section{References}

Abu Hammad, A., Børresen, T., 2006. Socioeconomic factors affecting farmers' perceptions of land degradation and stonewall terraces in Central Palestine. Environ. Manage. 37(3), 380-394.

Abu Hammad, A., Haugen, L.E., Børresen, T., 2004. Effects of stonewalled terracing techniques on soil-water conservation and wheat production under Mediterranean conditions. Environ. Manage. 34(5), 701-710.

Adgo, E., Teshome, A., Mati, B., 2013. Impacts of long-term soil and water conservation on agricultural productivity: The case of Anjenie watershed, Ethiopia. Agr. Water Manage. 117, 55-61.

Al Ali, Y., Touma, J., Zante, P., Nasri, S., Albergel, J., 2008. Water and sediment balances of a contour bench terracing system in a semi-arid cultivated zone (El Gouazine, central Tunisia). Hydrolog. Sci. J. 53(4), 883-892.

Andrew, B., James, C., 2011. Terraced fields and Mediterranean landscape structure: An analytical case study from Antikythera, Greece. Ecol. Model. 222(7), 1303-1314.

Antle, J.M., Stoorvogel, J.J., Valdivia, R.O., 2007. Assessing the economic impacts of agricultural carbon sequestration: Terraces and agroforestry in the Peruvian Andes. Agr. Ecosyst. Environ. 122(4), 435-445.

Appels, W.M., Bogaart, P.W., van der Zee, S.E.A.T.M., 2011. Influence of spatial variations of microtopography and infiltration on surface runoff and field scale hydrological connectivity. Adv. Water Resour. 34(2), 303-313.

Aquino, L.S., Timm, L.C., Reichardt, K., Barbosa, E.P., Parfitt, J.M.B., Nebel, A.L.C., Penning, L.H., 2015. State-space approach to evaluate effects of land levelling on the spatial relationships of soil properties of a lowland area. Soil Till. Res. 145, 135-147.

Armitage, A.R., Ho, C.K., Madrid, E.N., Bell, M.T., Quigg, A., 2014. The influence of habitat construction technique on the ecological characteristics of a restored brackish marsh. Ecol. Eng. 62(1), 33-42.

Bantayan, N.C., Calderon, M.M., Dizon, J.T., Sajise, A.J.U., Salvador, M., 2012. Estimating the Extent and Damage of the UNESCO World Heritage Sites of the Ifugao Rice Terraces, Philippines. J. Environ. Sci. Manag. 15(1), 1-5.

Barker, G.W., Adams, R., Creighton, O.H., Daly, P., Gilbertson, D.D., Grattan, J.P., Hunt, C.O., 

fourth (1999) season of the wadi faynan landscape survey. Levant 32(1), 27-52.

Bazzoffi, P., Abbattista, F., Vanino, S., Pellegrini, S., 2006. Impact of land levelling for vineyard plantation on soil degradation in Italy. B. Soc. Geol. Ital. 125(3), 191-199.

Beach, T., Luzzadder-Beach, S., Dunning, N., Hageman, J., Lohse, J., 2002. Upland agriculture in the Maya Lowlands: ancient Maya soil conservation in Northwestern Belize. The Geography Review 92 (3), 372-397.

Beckers, B., Schütt, B., Tsukamoto, S., Frechen, M., 2013. Age determination of Petra's engineered landscape - optically stimulated luminescence (OSL) and radiocarbon ages of runoff terrace systems in the Eastern Highlands of Jordan. J. Archaeol. Sci. 40(1), 333-348.

Bellin, N., Wesemael, B.V., Meerkerk, A., Vanacker, V., Barbera, G.G., 2009. Abandonment of soil and water conservation structures in Mediterranean ecosystems: a case study from south east Spain. Catena 76(2), 114-121.

Bergkamp, G., 1998. A hierarchical view of the interactions of runoff and infiltration with vegetation and microtopography in semiarid shrublands. Catena 33(3), 201 - 220.

Bizoza, A.R., Graaff, J. de., 2012. Financial cost-benefit analysis of bench terraces in Rwanda. Land Degrad. Dev. 23(2), 103-115.

Blécourt M. de, Hänsel V.M., BrummeR., Corre M.D., Veldkamp E., 2014. Soil redistribution by terracing alleviates soil organic carbon losses caused by forest conversion to rubber plantation. Forest Ecol. Manag. 313(2), 26-33.

Borejsza, A., Rodríguez López, I., Frederick, C.D., Bateman, M.D., 2008. Agricultural slope management and soil erosion at La Laguna, Tlaxcala, Mexico. J. Archaeol. Sci. 35(7), 1854-1866.

Borisov, A.V., Korobov, D.S., Simakova, A.N., Zanina, O.G., Bukhonov, A.V., Demidov, V.V., 2012. Ancient agricultural terraces in the Kislovodsk Depression: History and modern state of the soils. Eurasian Soil Sci. 45(6), 561-577.

Bragg, T.B.,Stephens, L.J., 1979. Effects of agricultural terraces on the reestablishment of bluestem grasslands. J. Range Manage. 32(6), 437-441.

Bruins, H.J., 2012. Ancient desert agriculture in the Negev and climate-zone boundary changes during average, wet and drought years. J. Arid Environ. 86(17), 28-42.

Calderon, M.M., Bantayan, N.C., Dizon, J.T., Sajise, A.J.U., Codilan, A.L., Canceran, M.S., 2015. Community-based resource assessment and management planning for the rice terraces of Hungduan, Ifugao, Philippines. J. Environ. Sci. Manag. 18(1), 47-53.

Castro, L.G., Libardi, P.L.,de Jong van Lier, Q., 2002. Soil water dynamics in a Brazilian infiltration terrace under different management practices. Sustainable Land Management - 
Environmental Protection 35, 191-198.

Chang, T.T., 1976. The rice cultures. Phil. Trans. R. Soc. Lond. B. 275, 143-157.

Chen, L.D., Wei, W., Fu, B.J., Lu, Y.H., 2007. Soil and water conservation on the Loess Plateau in China: review and perspective. Prog. Phys. Geog. 31(4), 389-403.

Chen, S. K., Chen, R. S., Yang, T.Y., 2014. Application of a tank model to assess the flood-control function of a terraced paddy field. Hydrolog. Sci. 59(5), 1020-1031.

Chen, S.K., Chen, W.L., Chen Y.R., 2012. Assessing soil erosion in a terraced paddy field using experimental measurements and universal soil loss equation. Catena 95(1), 131-141.

Chen, S.K., Chen, Y.R., Peng, Y.H., 2013. Experimental study on soil erosion characteristics in flooded terraced paddy fields. Paddy Water Environ. 11(1-4), 433-444.

Chow, T.L., Rees, H.W.,Daigle, J.L., 1999. Effectiveness of terraces/grassed waterway systems for soil and water conservation: A field evaluation. J. Soil Water Conserv. 54(3), 577-583.

Clark, H.H., Martin, J.M., Siddle, D.J., 1967. The agricultural history review. The British Agricultural History Society 1-146.

Cots-Folch, R., Martinez-Casasnovas, J.A., Ramos, M.C., 2006. Land terracing for new vineyard plantations in the north-eastern Spanish Mediterranean region: Landscape effects of the EU council regulation policy for vineyards' restructuring. Agr. Ecosyst. Environ. 115(1-4), 88-96.

Courtwright, J., Findlay, S.E.G., 2011. Effects of microtopography on hydrology, physicochemistry, and vegetation in a tidal swamp of the Hudson River. Wetlands 31(2), 239-249.

Cyffka, B., Bock, M., 2008. Degradation of field terraces in the Maltese Islands - reasons, processes and effects. Geogr. Fis. Din. Quat. 31(2), 119-128.

de Oliveira, J.R.S., Pruski, F.F., da Silva, J.M.A.,da Silva, D.P., 2012. Comparative analysis of the performance of mixed terraces and level and graded terraces. Acta Sci-Agron. 34(4), 351-357.

Díaz, A.R., Sanleandro, P.M., Soriano, A.S., Serrato, F.B., Faulkner, H., 2007. The causes of piping in a set of abandoned agricultural terraces in southeast Spain. Catena 69(3), 282-293.

Duarte, F., Jonesa, N., Fleskens, L., 2008. Traditional olive orchards on sloping land: Sustainability or abandonment? J. Environ. Manage. 89, 86-98.

Dumbrovsky, M., Sobotkova, V., Sarapatka, B., Chlubna, L., Vachalova, R., 2014. Cost-effectiveness evaluation of model design variants of broad-base terrace in soil erosion control. Ecol. Eng. 68, 260-269.

Dunning, N.P., Beach, T., 1994. Soil erosion, slope management, and ancient terracing in the Maya Lowlands. Latin American Antiquity 5(1), 51-69.

El Atta, H.A., Aref, I., 2010. Effect of terracing on rainwater harvesting and growth of Juniperus 
Evans, T.P., Winterhalder, B., 2000. Modified solar insolation as an agronomic factor in terraced environments. Land Degrad. Dev. 11(3), 273-287.

Frei, S., Lischeid, G., Fleckenstein, J.H., 2010. Effects of micro-topography on surface-subsurface exchange and runoff generation in a virtual riparian wetland - A modeling study. Adv. Water Resour. 33(11), 1388-1401.

Galletti, C.S., Ridder, E., Falconer, S.E., Fall, P.L., 2013. Maxent modeling of ancient and modern agricultural terraces in the Troodos foothills, Cyprus. Appl. Geogr. 39(1), 46-56.

Garcia-Franco, N., Wiesmeier, M., Goberna, M., Martinez-Mena, M., Albaladejo, J., 2014. Carbon dynamics after afforestation of semiarid shrublands: Implications of site preparation techniques. Forest Ecol. Manag. 319(5), 107-115.

Garcia-Ruiz, J.M., Nadal-Romero, E., Lana-Renault, N., Begueria, S., 2013. Erosion in Mediterranean landscapes: Changes and future challenges. Geomorphology 198(17), 20-36.

Goodman-Elgar, M., 2008. Evaluating soil resilience in long-term cultivation: a study of pre-Columbian terraces from the Paca Valley, Peru. J. Archaeol. Sci. 35(12), 3072-3086.

Groninger, J.W., 2012. Reforestation strategies amid social instability: Lessons from Afghanistan. Environ. Manage. 49(4), 833-845.

Hallema, D.W., Moussa, R., 2014. A model for distributed GIUH-based flow routing on natural and anthropogenic hillslopes. Hydrol. Process. 28(18), 4877-4895.

Haas, H.J., Willis, W.O., Boatwrig, G., 1966. Moisture storage and spring wheat yields on level-bench terraces as influenced by contributing area cover and evaporation control. Agron. J. 58(3), 297-299.

Hamdan, J., Burnham, C.P., Ruhana, B., 2000. Degradation effect of slope terracing on soil quality for Elaeis guineensis Jacq. (oil palm) cultivation. Land Degrad. Dev. 11(2), 181-193.

He, J.J., Cai, Q.G., Fang H.Y., 2009. Effect evaluation of spatial allocation of water and soil conservation measures in Zhangjiakou area. Trans. CSAE. 25(10), 69-75 (in Chinese with English Abstract).

Hill, R.D., Peart, M.R., 1998. Land use, runoff, erosion and their control: a review for southern China. Hydrol. Process. 12(13-14), 2029-2042.

Homburg, J.A., Sandor, J.A., 2011. Anthropogenic effects on soil quality of ancient agricultural systems of the American Southwest. Catena 85(2), 144-154.

Hobbs, R.J., Higgs, E., Hall, C.M., Bridgewater, P., Chapin, F.S., Ellis, E.C., Ewel, J.J., Hallett, L.M., Harris, J., Hulvey, K.B., Jackson, S.T., Kennedy, P.L., Kueffer, C., Lach, L., Lantz, T.C., Lugo, A.E., Mascaro, J., Murphy, S.D., Nelson, C.R., Perring, M.P., Richardson, D.M., Seastedt, T.R., Standish, R.J., Starzomski, B.M., Suding, K.N., Tognetti, P.M., Yakob, L., Yung, L., 2014. Managing the whole landscape: historical, hybrid, and novel ecosystems. 
Front. Ecol. Environ. 12(10), 557-564.

Hu, J.Q., An, Y.P., Li, Y.W., 2007. Comparative study of impact of different site preparation methods for afforestation efforts. J. Ning Xia Teach. Univ. 28(3), 110-113 (in Chinese with English Abstract).

Jiao, J.Y., Wang W.Z., 1999. Quality and soil-water conservation effectiveness of level terrace on the Loess Plateau. Trans. CSAE. 15(2), 59-63. (in Chinese with English Abstract).

Joshi, R.C., Delacruz, M.S., Martin, E.C., Cabigat, J.C., Bahatan, R.G., Bahatan, A.D., Abayao, E.H., Choy-Awon, J., Chilagan, N.P.,Cayong, A.B., 2001. Current status of the golden apple snail in the Ifugao rice terraces, Philippines. J. Sustain. Agr. 18(2-3), 71-90.

Kagabo, D.M., Stroosnijder, L., Visser, S.M., Moore, D., 2013. Soil erosion, soil fertility and crop yield on slow-forming terraces in the highlands of Buberuka, Rwanda. Soil Till. Res. 128, 23-29.

Kosulic, O., Michalko, R., Hula, V., 2014. Recent artificial vineyard terraces as a refuge for rare and endangered spiders in a modern agricultural landscape. Ecol. Eng. 68(7), 133-142.

Koulouri, M., Giourga, C., 2007. Land abandonment and slope gradient as key factors of soil erosion in Mediterranean terraced lands. Catena 69(3), 274-281.

Krahtopoulou, A., Frederick, C., 2008. The stratigraphic implications of long term terrace agriculture in dynamic landscapes: Polycyclic terracing from Kythera Island, Greece. Geoarchaeology 23(4), 550-585.

Kuijt, I., Finlayson, B., and MacKay, J., 2007. Pottery Neolithic landscape modification at Dhra'. Antiquity 81, 106-118.

Kumar, M., Singh, K.P., Srinivas, K., Reddy, K.S., 2014. In-situ water conservation in upland paddy field to improve productivity in north-west Himalayan region of India. Paddy Water Environ. 12(1), 181-191.

LaFevor, M.C., 2014. Restoration of degraded agricultural terraces: Rebuilding landscape structure and process. J. Environ. Manage. 138, 32-42.

Lasanta, T., Arnaez, J., Oserin, M., Ortigosa, L.M., 2001. Marginal lands and erosion in terraced fields in the Mediterranean mountains: A case study in the Camero Viejo (northwestern Iberian System, Spain). Mt. Res. Dev. 21(1), 69-76.

Lesschen, J.P., Cammeraat, L.H., Nieman, T., 2008. Erosion and terrace failure due to agricultural land abandonment in a semi-arid environment. Earth Surf. Proc. Land. 33(10), 1574-1584.

Li, X.H., Yang, J., Zhao, C.Y., Wang, B., 2014. Runoff and sediment from orchard terraces in southeastern China. Land Degrad. Dev. 25(2), 184-192.

Li, Y.M., Wang, K.Q., Liu, Z.Q., Wang, J.Y., Zhou X., 2006. Effect of measure of engineering preparation to soil water in Yunnan dry-hot river valley. J. Soil Water Conserv. 1(2): 15-19 (in Chinese with English abstract). 
Liu, M.C., Xiong, Y., Yuan, Z., Min, Q.W., Sun, Y.H., Fuller, A.M., 2014. Standards of ecological compensation for traditional eco-agriculture: Taking rice-fish system in Hani terrace as an example. J. Mt. Sci. 11(4), 1049-1059.

Liu, S.L., Dong, Y.H., Li, D., Liu, Q., Wang, J., Zhang, X.L., 2013. Effects of different terrace protection measures in a sloping land consolidation project targeting soil erosion at the slope scale. Ecol. Eng. 53, 46-53.

Liu, S.L, Wang, C., Zhang, X.L., 2008. Effect of soil and water conservation in different terrace configurations in land consolidation project. J. Soil Water Conserv. 25(4): 59-62 (in Chinese with English abstract).

Liu, X.H., He, B.L., Li, Z.X., Zhang, J.L., Wang, L., Wang, Z., 2011. Influence of land terracing on agricultural and ecological environment in the loess plateau regions of China. Environ. Earth Sci. 62(4), 797-807.

Lu, Y., Stocking, M., 2000. Integrating biophysical and socio-economic aspects of soil conservation on the Loess Plateau, China. Part III. The benefits of conservation. Land Degrad. Dev. 11(2), 153-165.

Luedeling, E., Nagieb, M., Wichern, F., Brandt, M., Deurer, M., Buerkert, A., 2005. Drainage, salt leaching and physico-chemical properties of irrigated man-made terrace soils in a mountain oasis of northern Oman. Geoderma 125(3-4), 273-285.

Mai, V.T., Van Keulen, H., Hessel, R., Ritsema, C., Roetter, R., Phien, T., 2013. Influence of paddy rice terraces on soil erosion of a small watershed in a hilly area of Northern Vietnam. Paddy Water Environ. 11(1-4), 285-298.

Martins, M.A.S., Machado, A.I., Serpa, D., Prats, S.A., Faria, S.R., Varela, M.E.T., Gonzalez-Pelayo, O., Keizer, J.J., 2013. Runoff and inter-rill erosion in a maritime pine and a eucalypt plantation following wildfire and terracing in north-central Portugal. J. Hydrol. Hydromech. 61(4), 261-268.

McConchie, J.A., Ma, H.C., 2002. A discussion of the risks and benefits of using rock terracing to limit soil erosion in Guizhou Province. J. Forest Res. 13(1), 41-47.

Montgomery, D.R., 2007. Soil erosion and agricultural sustainability. Proc. Natl. Acad. Sci. U.S.A. 104(33), 13268-13272.

Morgan, J.M., Condon, A.G., 1986. Water-use, grain-yield, and osmoregulation in wheat. Aust. J. Plant Physiol. 13(4), 523-532.

Moser, K.F., Ahn, C., Noe, G.B., 2009. The Influence of microtopography on soil nutrients in created mitigation wetlands. Restor. Ecol. 17(5), 641-651.

Nicod, J., 1990. Murettes et terrasses de culture dans les régions karstiques méditerranéennes. Méditerranée 71, 34-54.

Nyssen, J., Clymans, W., Poesen, J., Vandecasteele, I., De Baets, S., Haregeweyn, N., Naudts, J., Hadera, A., Moeyersons, J., Haile, M., Deckers, J., 2009. How soil conservation affects the 
catchment sediment budget- a comprehensive study in the north Ethiopian highlands. Earth Surf. Proc. Land. 34(9), 1216-1233.

Nyssen, J., Poesen, J., Moeyersons, J., Deckers, J., Haile, M., Lang, A., 2004. Human impact on the environment in the Ethiopian and Eritrean highlands - a state of the art. Earth Sci. Rev. 64(3-4), 273-320.

Ore, G., Bruins, H.J., 2012. Design features of ancient agricultural terrace walls in the Negev desert: human-made geodiversity. Land Degrad. Dev. 23(4), 409-418.

Pacheco, F.A.L., Varandas, S.G.P., Fernandes, L.F.S., Valle, R.F., 2014. Soil losses in rural watersheds with environmental land use conflicts. Sci. Total Environ. 485-486(3), 110-120.

Paoletti, M.G., 1999. Using bioindicators based on biodiversity to assess landscape sustainability. Agr. Ecosyst. Environ. 74(1-3), 1-18.

Park, J.Y., Yu, Y.S., Hwang, S.J., Kim, C., Kim, S.J., 2014. SWAT modeling of best management practices for Chungju dam watershed in South Korea under future climate change scenarios. Paddy Water Environ. 12(1), S65-S75.

Peng, H., Zhang, H.F., 2005. Development of theory and practice of eco-engineering and thoughts on present measures for slope control. J. Mount. Sci. 23(6), 729-735 (in Chinese with English abstract).

Petanidou, T., Kizos, T., Soulakellis, N., 2008. Socioeconomic dimensions of changes in the agricultural landscape of the Mediterranean basin: a case study of the abandonment of cultivation terraces on Nisyros Island, Greece. Environ. Manage. 41(2), 250-266.

Peter, K.D., Ries, J.B., 2013. Infiltration rates affected by land levelling measures in the Souss valley, South Morocco. Z. Geomorphol. 57(1), 59-72.

Pietsch, D., Mabit, L., 2012. Terrace soils in the Yemen Highlands: Using physical, chemical and radiometric data to assess their suitability for agriculture and their vulnerability to degradation. Geoderma 185-186(8), 48-60.

Posthumus, H., Graaff, J. de., 2005. Cost-benefit analysis of bench terraces, a case study in Peru. Land Degrad. Dev. 16(1), 1-11.

Posthumus, H., Stroosnijder, L., 2010. To terrace or not: the short-term impact of bench terraces on soil properties and crop response in the Peruvian Andes. Environ. Dev. Sustain. 12(2), 263-276.

Price, S., Nixon, L., 2005. Ancient Greek agricultural terraces: evidence from texts and archaeological survey. Amer. J. Archaeol. 109(4), 665-694.

Purwanto, E., Bruijnzeel, L. A., 1998. Soil conservation on rainfed bench terraces in upland West Java, Indonesia: towards a new paradigm. Adv. Geoecol. 31, 1267-1274.

Qiu, Z.M., Chen, B.X., Takemoto, K., 2014. Conservation of terraced paddy fields engaged with multiple stakeholders: the case of the Noto GIAHS site in Japan. Paddy Water Environ. 12(2), 
Raes, D., Gabriels, D., Kowsar, S.A., Corens, P., Esmaeili, N., 2008. Modeling the effect of floodwater spreading systems on the soil-water balance and crop production in the Gareh Bygone Plain of Southern Iran. Future Dryland. 243-254.

Ramos, M.C., Cots-Folch, R., Martinez-Casasnovas, J.A., 2007a. Effects of land terracing on soil properties in the Priorat region in Northeastern Spain: A multivariate analysis. Geoderma 142(3-4), 251-261.

Ramos, M.C., Cots-Folch, R., Martinez-Casasnovas, J.A., 2007b. Sustainability of modem land terracing for vineyard plantation in a Mediterranean mountain environment -The case of the Priorat region (NE Spain). Geomorphology 86(1-2), 1-11.

Ramos, M.C., Porta, J., 1997. Analysis of design criteria for vineyard terraces in the Mediterranean area of North East Spain. Soil Technol. 10(2), 155-166.

Rockström, J., Falkenmark, M., 2015. Agriculture: increase water harvesting in Africa. Nature 519(7543), 283-285.

Rodriguez, V.P.,Anderson, K.C., 2013. Terracing in the Mixteca Alta, Mexico: Cycles of resilience of an ancient land-use strategy. Human Ecology 41(3), 335-349.

Salvador-Blanes, S., Cornu, S., Couturier, A., King, D., Macaire, J.J., 2006. Morphological and geochemical properties of soil accumulated in hedge-induced terraces in the Massif Central, France. Soil Till. Res. 85(1-2), 62-77.

Sandor, J.A., Gersper, P.L., Hawley, J.W., 1990. Prehistoric agricultural terraces and soils in the Mimbres area, New Mexico. World Archaeol. 22(1), 70-86.

Sang-Arun J, Mihara M, Horaguchi Y, Yamaji E. 2006. Soil erosion and participatory remediation strategy for bench terraces in northern Thailand. Catena 65(3), 258-264.

Savo, V., Caneva, G., McClatchey, W., Reedy, D., Salvati, L., 2014. Combining environmental factors and agriculturalists' observations of environmental changes in the traditional terrace system of the Amalfi Coast (Southern Italy). AMBIO 43(3), 297-310.

Schiettecatte, W., Ouessar, M., Gabriels, D., Tanghe, S., Heirman, S., Abdelli, F., 2005. Impact of water harvesting techniques on soil and water conservation: a case study on a micro catchment in southeastern Tunisia. J. Arid Environ. 61(2), 297-313.

Schonbrodt-Stitt, S., Behrens, T., Schmidt, K., Shi, X.S., Scholten, T., 2013. Degradation of cultivated bench terraces in the Three Gorges Area: Field mapping and data mining. Ecol. Indic. 34(6), 478-493.

Shao, H., Baffaut, C., Gao, J.E., Nelson, N.O., Janssen, K.A., Pierzynski, G.M.,Barnes, P.L., 2013. Development and application of algorithms for simulating terraces within SWAT. Trans. Asabe. 56(5), 1715-1730.

Sharda, V.N., Juyal, G.P., Singh, P.N., 2002. Hydrologic and sedimentologic behavior of a 
conservation bench terrace system in a sub-humid climate. Trans. Asae. 45(5), 1433-1441.

Sharda, V.N., Sena, D.R., Shrimali, S.S., 2013. Effects of an intercrop-based conservation bench terrace system on resource conservation and crop yields in a sub-humid climate in India. Trans. Asabe. 56(4), 1411-1425.

Sharifi, A., Gorji, M., Asadi, H., Pourbabaee, A.A., 2014. Land leveling and changes in soil properties in paddy fields of Guilan province, Iran. Paddy Water Environ. 12(1), 139-145.

Shi, Y.F., 2013. Experimental study of different afforestation on the growth of walnut. Forest By-Product and Speciality in China 2013 (6), 38-39 (in Chinese with English abstract).

Shimeles, D., Lulseged, T., Paul, L.G.V., 2012. Performance of farmland terraces in maintaining soil fertility: a case of Lake Maybar watershed in Wello, northern highlands of Ethiopia. J. Life Sci. 6, 1251-1261.

Stanchi, S., Freppaz, M., Agnelli, A., Reinsch, T., Zanini, E., 2012. Properties, best management practices and conservation of terraced soils in Southern Europe (from Mediterranean areas to the Alps): A review. Quatern. Int. 265, 90-100.

Stavi, I., Fizik, E., Argaman, E., 2015. Contour bench terrace (shich/shikim) forestry systems in the semi-arid Israeli Negev: Effects on soil quality, geodiversity, and herbaceous vegetation. Geomorphology 231, 376-382.

Sun, Y.H., Zhou, H.J., Zhang, L.Y., Min, Q.W., Yin, W.X., 2013. Adapting to droughts in Yuanyang Terrace of SW China: insight from disaster risk reduction. Mitig Adapt Strat Gl 18(6), 759-771.

Taddese, G., 2001. Land degradation: a challenge to Ethiopia. Environ. Manage. 27(6), 815-824.

Tarolli, P., Preti, F., Romano, N., 2014. Terraced landscapes: From an old best practice to a potential hazard for soil degradation due to land abandonment. Anthropocene 6, 10-25.

Thomas, D.B., Barber, R.G., Moore, T.R., 1980. Terracing of cropland in low rainfall areas of Machakos District, Kenya. J. Agr. Eng. Res. 25(1), 57-63.

Thompson, S.E., Katul, G.G., Porporato, A., 2010. Role of microtopography in rainfall-runoff partitioning: An analysis using idealized geometry. Water Resour. Res. 46, W07520.

Tiwari, K.R., Sitaula, B.K., Bajracharya, R.M., Børresen, T., 2009. Runoff and soil loss responses to rainfall, land use, terracing and management practices in the Middle Mountains of Nepal. Acta Agr. Scand. 59(3), 197-207.

Tokuoka, Y., Hashigoe, K., 2015. Effects of stone-walled terracing and historical forest disturbances on revegetation processes after the abandonment of mountain slope uses on the Yura Peninsula, southwestern Japan. J Forest Res-Jpn 20(1), 24-34.

UNESCO, 2008. The effects of tourism on culture and the environment in Asia and the Pacific, sustainable tourism and the preservation of the world heritage site of the Ifugao Rice Terraces, Philippines. 
Van Dijk, A., Bruijnzeel, L.A., 2004. Runoff and soil loss from bench terraces. 1. An event based model of rainfall infiltration and surface runoff. Eur. J. Soil Sci. 55 (2), 299-316.

Van Dijk, A., Bruijnzeel, L.A., Vertessy, R.A., Ruijter, J., 2005. Runoff and sediment generation on bench-terraced hillsides: measurements and up-scaling of a field-based model. Hydrol. Process. 19(8), 1667-1685.

Wang, Q.G., Bai, J.H., Huang, L.B., Deng, W., Xiao, R., Zhang, K.J., 2011. Soil nutrient distribution in two typical paddy terrace wetlands along an elevation gradient during the fallow period. J. Mount. Sci. 8(3), 476-483.

Wei, W., Chen, L.D., Yang, L., Samadani, F.F., Sun, G., 2012. Microtopography recreation benefits ecosystem restoration. Environ. Sci. Technol. 46(20), 10875-10876.

Wen, B.L., Ren, G., Zhang, N.M., 2009. Soil nutrient vertical variance of Hani terraced field in Yuanyang County of Yunnan Province. J. Yunnan Agric. Univ. 24 (1), 78-81(in Chinese with English abstract).

Wheaton R.Z., Monke, E.J., 1981. Terracing as a "Best Management Practice" for Controlling Erosion and Protecting Water Quality. Agricultural Engineering Department, Purdue University. https://www.extension.purdue.edu/extmedia/ae/ae-114.html

Wickama, J., Okoba, B., Sterk, G., 2014. Effectiveness of sustainable land management measures in West Usambara highlands, Tanzania. Catena 118, 91-102.

Williams, L.S., 1990. Agricultural terrace evolution in Latin America. University of Texas Press 16, 82-93.

Xu, Q.X., Wang, T.W., Cai, C.F., Li, Z.X., Shi, Z.H., 2012. Effects of soil conservation on soil properties of citrus orchards in the Three-Gorges Area, China. Land Degrad. Dev. 23(1), 34-42.

Yang, Q., Meng, F.R., Zhao, Z.Y., Chow, T.L., Benoy, G., Rees, H.W., Bourque, C.P.A., 2009. Assessing the impacts of flow diversion terraces on stream water and sediment yields at a watershed level using SWAT model. Agr. Ecosyst. Environ. 132(1-2), 23-31.

Yang, S.Y., Ma, D.B., 2004. Talk about the measures to improve the rate of productivity and water use of irrigation water. Water Conserv. 7, 44-45 (in Chinese with English abstract).

Yang, T.B., Wang, S.L., Yang, W.H., 2014. Construction design and cost estimation on the machine building terraces. Soil Water Conserv. China 1, 25-27. (in Chinese with English abstract).

Yuan, Z., Lun, F., He, L., Cao, Z., Min, Q.W., Bai, Y.Y., Liu, M.C., Cheng, S.K., Li, W.H., Fuller, A.M., 2014. Exploring the State of Retention of Traditional Ecological Knowledge (TEK) in a Hani Rice Terrace Village, Southwest China. Sustainability 6(7), 4497-4513.

Zhang, J.Y., Yang, J., Wang, Z.Y, 2010. Study on sediment characteristics of different types of terrace in hilly red soil region of abortion. Yangtze River (14), 99-103 (in Chinese with English abstract). 
Zhang, Q.W., Li, Y., 2014. Effectiveness assessment of soil conservation measures in reducing soil erosion in Baiquan County of Northeastern China by using Cs-137 techniques. Environ. Sci. Proc. Impacts 16(6), 1480-1488.

Zhang, W.G., Cao, L. P., 2008. Study of the effects on reverse slope terrace site preparation. Prot. Forest Sci. Technol. 5(86), 129-130(in Chinese with English abstract).

Zhao, Q.Z., Cai, J.Q., 2012. Micro-catchment cultivation on growth and yield of dryland crop traits of terraced fields. Shanxi Agric. Sci. 40(6), 624-627 (in Chinese with English abstract).

Zhu, X.Q., Fang, T.L., 2009. Experimental study on the growth of different preparations for afforestation on the results of the impact of Chinese Pine. Shaanxi Agric. Sci. 55(1), 52-53(in Chinese with English abstract).

Zuazo, V.H.D., Ruiz, J.A., Raya, A.M., Tarifa, D.F., 2005. Impact of erosion in the taluses of subtropical orchard terraces. Agr. Ecosyst. Environ. 107(2-3), 199-210.

(1) 


\begin{abstract}
For thousands of years, humans have created different types of terraces in different sloping conditions, meant to mitigate flood risks, reduce soil erosion and conserve water. These anthropogenic landscapes can be found in tropical and subtropical rainforests, deserts, arid and semiarid mountains across the globe. Despite the long history, the roles of and the mechanisms by which terracing improves ecosystem services (ES) remain poorly understood. Using literature synthesis and quantitative analysis, the worldwide types, distributions, major benefits and issues of terracing are presented in this review. A key terracing indicator, defined as the ratio of different ES under terraced and non-terraced slopes $(\delta)$, was used to quantify the role of terracing in providing ES. Our results indicated that ES provided by terracing was generally positive because the mean values of $\delta$ were mostly greater than one. The most prominent role of terracing was found in erosion control (11.46 $\pm 2.34)$, followed by runoff reduction $(2.60 \pm 1.79)$, biomass accumulation (1.94 \pm $0.59)$, soil water recharge $(1.20 \pm 0.23)$, and nutrient enhancement $(1.20 \pm 0.48)$. Terracing, to a lesser extent, could also enhance the survival rates of plant seedlings, promote ecosystem restoration, and increase crop yields. While slopes experiencing severe human disturbance (e.g., overgrazing and deforestation) can generally become more stable after terracing, negative effects of terracing may occur in poorly-designed or poorly-managed terraces. Among the reasons are the lack of environmental legislation, changes in traditional concepts and lifestyles of local people, as well as price decreases for agricultural products. All of these can accelerate terrace abandonment and degradation. In light of these findings, possible solutions regarding socio-economic changes and techniques to improve already degraded terraces are discussed.
\end{abstract}


Table 1 The ancient terraces in different countries of the world.

\begin{tabular}{|c|c|c|c|c|c|c|c|}
\hline Terraces & Country & Area $\left(\mathrm{hm}^{2}\right)$ & Building Time & Terrace type & $\begin{array}{l}\text { Current } \\
\text { Condition }\end{array}$ & Date of Inscription & Functions and Services \\
\hline Battir hill terraces & Palestine & 349 & 5000 years ago & Stone terraces & $\begin{array}{l}\text { Badly } \\
\text { maintained }\end{array}$ & $\begin{array}{l}\text { UNESCO World } \\
\text { Heritage Site, } 2014\end{array}$ & Orchards \\
\hline Ibb terraces & Yemen & 250000 & 5000 years ago & Dryland terraces & $\begin{array}{l}\text { Partially } \\
\text { abandoned }\end{array}$ & _ & $\begin{array}{l}\text { Land degradation control, coffee } \\
\text { cultivation, tourism }\end{array}$ \\
\hline Ouadi Qadisha terraces & Lebanon & 95000 & 2500 years ago & $\begin{array}{l}\text { Stone walled } \\
\text { bench terraces }\end{array}$ & $\begin{array}{l}\text { Severely } \\
\text { degradation }\end{array}$ & $\begin{array}{l}\text { UNESCO World } \\
\text { Heritage Site, } 1998\end{array}$ & $\begin{array}{l}\text { Grain cultivation, reducing erosion and } \\
\text { water flow, increasing productivity }\end{array}$ \\
\hline $\begin{array}{l}\text { Rice terraces of the Philippine } \\
\text { Cordilleras }\end{array}$ & Philippine & 10880 & 2000 years ago & Rice terraces & $\begin{array}{l}\text { Partially } \\
\text { collapsed }\end{array}$ & $\begin{array}{l}\text { UNESCO World } \\
\text { Heritage Site, } 1995 \\
\text { GIAHS,2002 }\end{array}$ & $\begin{array}{l}\text { Water storage, rice cultivation, sightseeing, } \\
\text { cultural education }\end{array}$ \\
\hline Hani terraces & China & 16603 & 1300 years ago & Rice terraces & $\begin{array}{l}\text { Well } \\
\text { maintained }\end{array}$ & $\begin{array}{l}\text { UNESCO World } \\
\text { Heritage Site, } 2013 \\
\text { GIAHS, } 2010\end{array}$ & $\begin{array}{l}\text { Rice cultivation, biodiversity, soil and } \\
\text { water conservation, sightseeing, historical } \\
\text { education, ethnic cultural value }\end{array}$ \\
\hline Ziquejie terrace & China & 1333 & 2000 years ago & Rice terrace & $\begin{array}{l}\text { Well } \\
\text { maintained }\end{array}$ & - & $\begin{array}{l}\text { Rice cultivation, water management, ethnic } \\
\text { cultural value }\end{array}$ \\
\hline Terraces of the Bahá'í Faith & Israel & 540000 & $\begin{array}{l}8 \text { th to } 10 \text { th } \\
\text { century }\end{array}$ & Dryland terraces & $\begin{array}{l}\text { Well } \\
\text { maintained }\end{array}$ & $\begin{array}{l}\text { UNESCO World } \\
\text { Heritage Site, } 2012\end{array}$ & Tourism, runoff retention \\
\hline Cinque terre terraces & Italy & 4689 & 8th century & Stone walled & Partially & UNESCO World & Viticulture, olive groves \\
\hline
\end{tabular}




\begin{tabular}{|c|c|c|c|c|c|c|c|}
\hline & & & & terraces & abandoned & Heritage Site, 1997 & \\
\hline Wachau vineyard terraces & Austria & 18387 & 9th century & $\begin{array}{l}\text { Vineyard } \\
\text { terraces }\end{array}$ & $\begin{array}{l}\text { Well } \\
\text { maintained }\end{array}$ & $\begin{array}{l}\text { UNESCO World } \\
\text { Heritage Site, } 2000\end{array}$ & Viticulture, sightseeing \\
\hline Bali Tegallalang terraces & Indonesia & 19520 & 9th century & Rice terraces & $\begin{array}{l}\text { Well } \\
\text { maintained }\end{array}$ & $\begin{array}{l}\text { UNESCO World } \\
\text { Heritage Site, } 2012\end{array}$ & $\begin{array}{l}\text { Coffee plantation, soil and water } \\
\text { conservation }\end{array}$ \\
\hline Lavaux vineyard terraces & Switzerland & 898 & 11 th century & $\begin{array}{l}\text { Stone walled } \\
\text { terraces }\end{array}$ & $\begin{array}{l}\text { Well } \\
\text { maintained }\end{array}$ & $\begin{array}{l}\text { UNESCO World } \\
\text { Heritage Site, } 2007\end{array}$ & Viticulture, sightseeing \\
\hline Serra de Tramuntana terraces & Spain & 30745 & 13th century & $\begin{array}{l}\text { Stone walled } \\
\text { terraces }\end{array}$ & $\begin{array}{l}\text { Partially } \\
\text { abandoned }\end{array}$ & $\begin{array}{l}\text { UNESCO World } \\
\text { Heritage Site, } 2011\end{array}$ & Orchards, vegetable gardens, olive groves \\
\hline Machu Picchu terraces & Peru & 2471053 & $\begin{array}{l}13 \text { th to } 14 \text { th } \\
\text { century }\end{array}$ & $\begin{array}{l}\text { Stone walled } \\
\text { terraces }\end{array}$ & Abandoned & $\begin{array}{l}\text { UNESCO World } \\
\text { Heritage Site, 1983; } \\
\text { GIAHS, } 2011\end{array}$ & $\begin{array}{l}\text { Potato cultivation, climate regulation, water } \\
\text { management }\end{array}$ \\
\hline Noto Peninsula terraces & Japan & 186600 & $\begin{array}{l}14 \text { th to } 16 \text { th } \\
\text { century }\end{array}$ & $\begin{array}{l}\text { Stone walled } \\
\text { rice terraces }\end{array}$ & $\begin{array}{l}\text { Partially } \\
\text { abandoned }\end{array}$ & GIAHS, 2011 & $\begin{array}{l}\text { Water retention, landslide prevention, } \\
\text { ecosystem conservation, scenic value }\end{array}$ \\
\hline $\begin{array}{l}\text { Al Jabal Al Akhdar Aflaj and } \\
\text { terraced fields system }\end{array}$ & Oman & 160000 & 500 years ago & Irrigated terraces & $\begin{array}{l}\text { Badly } \\
\text { maintained }\end{array}$ & - & $\begin{array}{l}\text { Food security, soil and water conservation, } \\
\text { climate regulation, carbon sequestration }\end{array}$ \\
\hline Gudeuljangnon rice terraces & $\begin{array}{l}\text { South } \\
\text { Korea }\end{array}$ & 4195 & 16th century & $\begin{array}{l}\text { Stone rice } \\
\text { terraces }\end{array}$ & $\begin{array}{l}\text { Well } \\
\text { maintained }\end{array}$ & GIAHS, 2014 & $\begin{array}{l}\text { Soil and water conservation, enrich } \\
\text { biodiversity }\end{array}$ \\
\hline Sukur terraces & Nigeria & 764.40 & 16th century & Dry stone & Well & UNESCO World & Soil and water conservation, cultural \\
\hline
\end{tabular}




\begin{tabular}{|c|c|c|c|c|c|c|c|}
\hline & & & & terraces & maintained & Heritage Site, 1999 & education \\
\hline Konso terraces & Ethiopia & 23000 & 400 years ago & $\begin{array}{l}\text { Stone walled } \\
\text { terraces }\end{array}$ & $\begin{array}{l}\text { Well } \\
\text { maintained }\end{array}$ & $\begin{array}{l}\text { UNESCO World } \\
\text { Heritage Site, } 2011\end{array}$ & Prevent erosion, collect water \\
\hline Sapa terraces & Vietnam & N/A & 18 th century & Rice terraces & $\begin{array}{l}\text { Well } \\
\text { maintained }\end{array}$ & - & Reduce runoff and soil erosion, tourism \\
\hline Douro vineyard terraces & Portugal & 24600 & 18th century & $\begin{array}{l}\text { Vineyard } \\
\text { terraces }\end{array}$ & $\begin{array}{l}\text { Well } \\
\text { maintained }\end{array}$ & $\begin{array}{l}\text { UNESCO World } \\
\text { Heritage Site, } 2001\end{array}$ & Viticulture, tourism \\
\hline
\end{tabular}

Note: UNESCO and GIAHS refer to "United Nations Educational, Scientific and Cultural Organization" and "Globally Important Agricultural Heritage Systems", respectively. 
Table 2 Worldwide research cases and major findings of terracing.

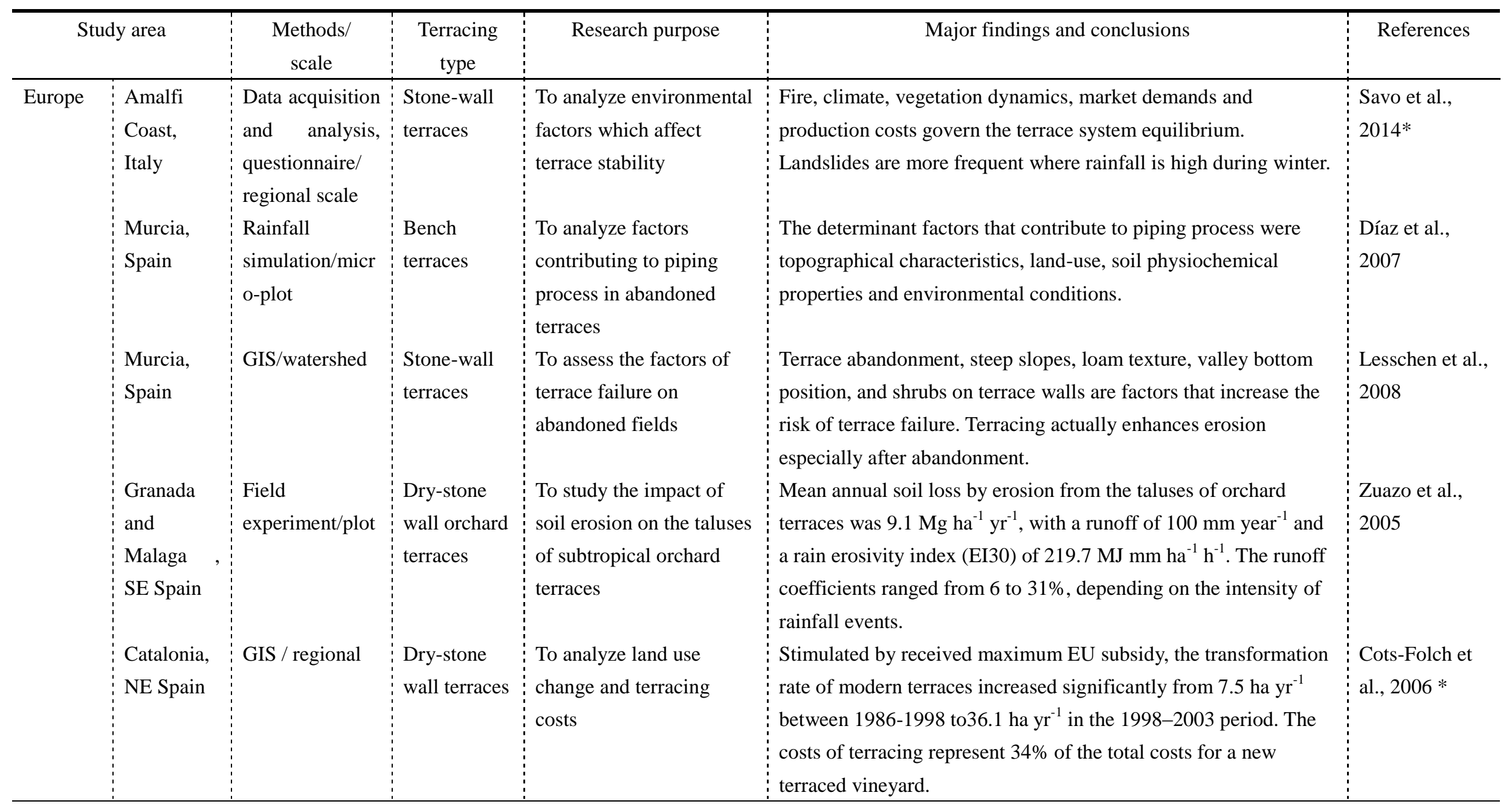




\begin{tabular}{|c|c|c|c|c|c|}
\hline $\begin{array}{l}\text { Sever do } \\
\text { Vouga, } \\
\text { Portugal }\end{array}$ & Plot experiment & $\begin{array}{l}\text { Afforestatio } \\
\text { n terraces }\end{array}$ & $\begin{array}{l}\text { Effect of terracing on } \\
\text { overland flow and } \\
\text { associated sediment } \\
\text { losses }\end{array}$ & $\begin{array}{l}\text { Terracing increased runoff volumes and erosion rates, Eucalypt } \\
\text { terraces produced } 3 \text { times more of sediments than Pine terraces. }\end{array}$ & $\begin{array}{l}\text { Martins et al., } \\
2013\end{array}$ \\
\hline $\begin{array}{l}\text { Douro, } \\
\text { Portugal }\end{array}$ & $\begin{array}{l}\text { USLE, } \\
\text { GIS/watershed }\end{array}$ & $\begin{array}{l}\text { Stone dike } \\
\text { vineyard } \\
\text { terraces }\end{array}$ & $\begin{array}{l}\text { Investigating land use } \\
\text { conflicts }\end{array}$ & $\begin{array}{l}\text { Water erosion is the major cause of hillside instability. Soil losses } \\
\text { could be reduced by terracing management with covered crops. }\end{array}$ & $\begin{array}{l}\text { Pacheco et al., } \\
2014\end{array}$ \\
\hline $\begin{array}{l}\text { Tuscany } \\
\text { and Emilia } \\
\text { Romagna, } \\
\text { Italy }\end{array}$ & $\begin{array}{l}\text { USLE } \\
\text { /watershed }\end{array}$ & $\begin{array}{l}\text { Dry-stone } \\
\text { wall terraces }\end{array}$ & $\begin{array}{l}\text { To evaluate the increasing } \\
\text { degradation levels of } \\
\text { stone wall terraces }\end{array}$ & $\begin{array}{l}\text { The average soil loss ranged between } 8640 \text { and } 23040 \mathrm{t} \mathrm{ha}^{-1} \text {, } \\
\text { while it decreased to } 260 \text { and } 537 \mathrm{t} \mathrm{ha}^{-1} \text { after land levelling. }\end{array}$ & $\begin{array}{l}\text { Bazzoffi et al, } \\
2006\end{array}$ \\
\hline $\begin{array}{l}\text { Lesvos } \\
\text { Island, } \\
\text { Greece }\end{array}$ & Field study/plot & $\begin{array}{l}\text { Sloping } \\
\text { terraces }\end{array}$ & $\begin{array}{l}\text { Effects of slope gradient } \\
\text { and terrace abandonment } \\
\text { on sediment loss }\end{array}$ & $\begin{array}{l}\text { When slope gradient reached } 25 \% \text {, soil erosion increased } \\
\text { significantly after terrace abandonment due to changes in } \\
\text { vegetation cover. When the slope gradient was } 40 \% \text { or higher, } \\
\text { sediment loss remained stable after terrace abandonment. }\end{array}$ & $\begin{array}{l}\text { Koulouri and } \\
\text { Giourga, } \\
2007 *\end{array}$ \\
\hline $\begin{array}{l}\text { Maltese } \\
\text { islands }\end{array}$ & GIS/watershed & $\begin{array}{l}\text { Stone dike } \\
\text { terraces }\end{array}$ & $\begin{array}{l}\text { To assess the possible } \\
\text { erosion tracks }\end{array}$ & $\begin{array}{l}\text { Cultivated terraces were protected by crops, farmer's care and } \\
\text { rubble walls. Intensive soil erosion occurred once rubble walls } \\
\text { collapsed. }\end{array}$ & $\begin{array}{l}\text { Cyffka and } \\
\text { Bock, } 2008 *\end{array}$ \\
\hline $\begin{array}{l}\text { Kislovodsk } \\
\text { Depression } \\
\text {, Russia }\end{array}$ & $\begin{array}{l}\text { Field survey/ } \\
\text { slope }\end{array}$ & $\begin{array}{l}\text { Ancient } \\
\text { agricultural } \\
\text { terraces }\end{array}$ & The origin of the terraces & $\begin{array}{l}\text { Up to } 60-70 \% \text { of the sloping areas and inter fluvial plateaus at the } \\
\text { heights of } 900 \text { to } 1500 \mathrm{~m} \text { a.s.l. were terraced during the Late } \\
\text { Bronze-Early Iron ages ( } 1200-600 \mathrm{BC}) \text {. }\end{array}$ & $\begin{array}{l}\text { Borisov et al., } \\
2012 *\end{array}$ \\
\hline $\begin{array}{l}\text { South } \\
\text { Moravian, } \\
\text { Czech } \\
\text { Republic }\end{array}$ & $\begin{array}{l}\text { Field survey/ } \\
\text { micro-habitat to } \\
\text { landscape scale }\end{array}$ & $\begin{array}{l}\text { Furrowed } \\
\text { broad-base } \\
\text { terraces }\end{array}$ & $\begin{array}{l}\text { Key factors affecting the } \\
\text { diversity of spiders in the } \\
\text { terraces }\end{array}$ & $\begin{array}{l}\text { Vineyard terraces created important refuges and replacement } \\
\text { bio-topes through their heterogeneous mosaic of micro-habitats, } \\
\text { thus increasing landscape biodiversity. Rare and endangered } \\
\text { epigeic species were associated with terraces having sparse } \\
\text { vegetation while rare epiphytic species were associated with }\end{array}$ & $\begin{array}{l}\text { Kosulic et al., } \\
2014\end{array}$ \\
\hline
\end{tabular}




\begin{tabular}{|c|c|c|c|c|c|c|}
\hline & $\begin{array}{l}\text { Massif } \\
\text { Central, } \\
\text { France }\end{array}$ & GIS/watershed & $\begin{array}{l}\text { Hedge-induc } \\
\text { ed terraces }\end{array}$ & $\begin{array}{l}\text { To quantify and explain } \\
\text { the origin of the } \\
\text { morphological and } \\
\text { geo-chemical properties } \\
\text { of terraces }\end{array}$ & $\begin{array}{l}\text { terraces having dense vegetation. } \\
\text { The formation of the terraces was mainly due to soil redistribution } \\
\text { through tillage. The stock of } \mathrm{Ca}, \mathrm{Mg}, \mathrm{K}, \mathrm{Fe} \text { and } \mathrm{Cr} \text { mainly came } \\
\text { from soil mechanical redistribution, while } \mathrm{Mn} \text { and Co probably } \\
\text { resulted from both mechanical and geochemical redistribution. }\end{array}$ & $\begin{array}{l}\text { Salvador-Blan } \\
\text { es et al., } 2006\end{array}$ \\
\hline \multirow[t]{5}{*}{ America } & $\begin{array}{l}\text { New } \\
\text { Brunswick } \\
\text { Canada }\end{array}$ & Plot experiment & $\begin{array}{l}\text { Terraces/gra } \\
\text { ssed } \\
\text { waterway } \\
\text { systems }\end{array}$ & $\begin{array}{l}\text { To quantify the benefits } \\
\text { of terracing on soil and } \\
\text { water conservation }\end{array}$ & $\begin{array}{l}\text { Contour planting of potatoes associated with terracing will reduce } \\
\text { runoff by as much as } 150 \mathrm{~mm} \text { of rainfall equivalent. Soil losses } \\
\text { were reduced from } 20 \mathrm{t} / \mathrm{ha} / \mathrm{yr} \text { to } 1 \mathrm{t} / \mathrm{ha} / \mathrm{yr} \text {. Terracing also makes } \\
\text { drainage basin hydrological characteristics less prone to ditch and } \\
\text { stream flooding. }\end{array}$ & $\begin{array}{l}\text { Chow et al., } \\
1999 *\end{array}$ \\
\hline & $\begin{array}{l}\text { New } \\
\text { Brunswick } \\
\text {, Canada }\end{array}$ & $\begin{array}{l}\text { SWAT model } \\
\text { /watershed }\end{array}$ & $\begin{array}{l}\text { Grass ridge } \\
\text { terraces }\end{array}$ & $\begin{array}{l}\text { To estimate the efficacy } \\
\text { of flow diversion terraces } \\
\text { (FDT) on water and } \\
\text { sediment yields }\end{array}$ & $\begin{array}{l}\text { FDT reduced sediment and water yields by } 4 \mathrm{t} \mathrm{ha}^{-1} \mathrm{yr}^{-1} \text { and } 158 \\
\mathrm{~mm} \mathrm{yr}^{-1} \text { on average, representing a total reduction of } 56 \% \text { and } \\
20 \% \text {, respectively. }\end{array}$ & $\begin{array}{l}\text { Yang et al., } \\
2009 *\end{array}$ \\
\hline & $\begin{array}{l}\text { Kansas, } \\
\text { America }\end{array}$ & $\begin{array}{l}\text { SWAT } \\
\text { model/watershe } \\
\text { d }\end{array}$ & $\begin{array}{l}\text { Level } \\
\text { benches }\end{array}$ & $\begin{array}{l}\text { To test and validate the } \\
\text { SWAT model on a } \\
\text { terraced fields }\end{array}$ & $\begin{array}{l}\text { Runoff and sediment were simulated with acceptable errors, } \\
\text { predicting the multiple effects of terraces on runoff, sediment, } \\
\text { nutrient transport, and groundwater recharge. }\end{array}$ & Shao et al., 2013 \\
\hline & $\begin{array}{l}\text { Nebraska, } \\
\text { America }\end{array}$ & Plot experiment & $\begin{array}{l}\text { Agricultural } \\
\text { terraces }\end{array}$ & $\begin{array}{l}\text { To evaluate the effects of } \\
\text { agricultural terraces on the } \\
\text { reestablishment of } \\
\text { grasslands }\end{array}$ & $\begin{array}{l}\text { It is advisable to remove terraces and redistribute terrace soil prior } \\
\text { to seeding cultivated land to native grasses }\end{array}$ & $\begin{array}{l}\text { Bragg and } \\
\text { Stephens, } 1979\end{array}$ \\
\hline & $\begin{array}{l}\text { Illinois, } \\
\text { America }\end{array}$ & $\begin{array}{l}\text { Model } \\
\text { simulation/ } \\
\text { watershed }\end{array}$ & $\begin{array}{l}\text { Level } \\
\text { benches }\end{array}$ & $\begin{array}{l}\text { To calculate incident solar } \\
\text { radiation falling on } \\
\text { terraced and un-terraced } \\
\text { fields in steep slope }\end{array}$ & $\begin{array}{l}\text { The SOLARCAL model shows that a terraced hillslope receives a } \\
\text { significantly different amount of direct solar radiation compared } \\
\text { to an un-terraced hillslope. This difference is a function of } \\
\text { latitude, slope aspect, slope angle, and seasonality. }\end{array}$ & $\begin{array}{l}\text { Evans and } \\
\text { Winterhalder, } \\
2000\end{array}$ \\
\hline
\end{tabular}




\begin{tabular}{|c|c|c|c|c|c|}
\hline & & & environments & & \\
\hline North & Plot experiment & Level & The effect of terraces on & Level bench increased moisture storage by 1.3 inches and wheat & Haas et al., \\
\hline Dakota, & & benches & moisture storage and & yields by 4.7 bushels per acre. The cost of construction may limit & $1966 *$ \\
\hline America & & & spring wheat yields & $\begin{array}{l}\text { bench installation, and such cost may be as high as } 15 \text { cents per } \\
\text { lineal foot for a bench } 50 \text { feet wide. }\end{array}$ & \\
\hline Rio & State-space & Level & Effects of land leveling & Land leveling induced negative effects on soil quality since it & Aquino et al., \\
\hline Grande do & approach & benches & on spatial relationships of & decreased the water contents at field capacity and permanent & 2015 \\
\hline Sul, Brazil & /watershed & & soil properties & $\begin{array}{l}\text { wilting point, soil organic carbon, cation exchange capacity and } \\
\text { soil bulk density. }\end{array}$ & \\
\hline Minas & Plot experiment & Level and & To carry out a comparative & Mixed terraces have a lower height than level terraces and a higher level & de Oliveira et \\
\hline Gerais & & graded & analysis between mixed & than the graded terraces, resulting in direct consequences for the soil & al., 2012 \\
\hline State, Brazil & & terraces & $\begin{array}{l}\text { terraces and level and graded } \\
\text { terraces }\end{array}$ & movement for the terrace construction. & \\
\hline Southeast & Plot experiment & Level & To evaluate the hydrological & The highest volumes and flux densities of water in the terrace canal & Castro et al., \\
\hline $\begin{array}{l}\text { Tlaxcala, } \\
\text { Mexico }\end{array}$ & $\begin{array}{l}\text { Field } \\
\text { measurement }\end{array}$ & $\begin{array}{l}\text { Agricultural } \\
\text { terraces }\end{array}$ & $\begin{array}{l}\text { To examine the key roles } \\
\text { of terrace in repairing } \\
\text { degraded agricultural land }\end{array}$ & $\begin{array}{l}\text { Methods of wildland restoration and agricultural restoration may } \\
\text { differ in the degree to which the latter must plan for and facilitate } \\
\text { a sustained human involvement }\end{array}$ & LaFevor, $2014 *$ \\
\hline $\begin{array}{l}\text { Mixteca } \\
\text { Alta region, } \\
\text { Mexico }\end{array}$ & $\begin{array}{l}\text { Data } \\
\text { intergradation } / \mathrm{r} \\
\text { egional scale }\end{array}$ & $\begin{array}{l}\text { Agricultural } \\
\text { terraces }\end{array}$ & $\begin{array}{l}\text { To document the history } \\
\text { of terracing }\end{array}$ & $\begin{array}{l}\text { Different stages in the history of terracing show parallels with the } \\
\text { adaptive cycles of a resilient system }\end{array}$ & $\begin{array}{l}\text { Rodriguez, } \\
2013^{*}\end{array}$ \\
\hline $\begin{array}{l}\text { Tlaxcala, } \\
\text { Mexico }\end{array}$ & $\begin{array}{l}\text { Field survey } \\
\text { and radiocarbon } \\
\text { dating }\end{array}$ & $\begin{array}{l}\text { Agricultural } \\
\text { terraces }\end{array}$ & $\begin{array}{l}\text { To date the construction } \\
\text { of terraces }\end{array}$ & $\begin{array}{l}\text { Stone-walled terraces were built in } 1150 \text { to } 1520 \text {. Renewed } \\
\text { reclamation has been undertaken since the Colonial period, } \\
\text { eventually taking the form of sloping-field terraces with berms }\end{array}$ & $\begin{array}{l}\text { Borejsza et al., } \\
2008 *\end{array}$ \\
\hline
\end{tabular}




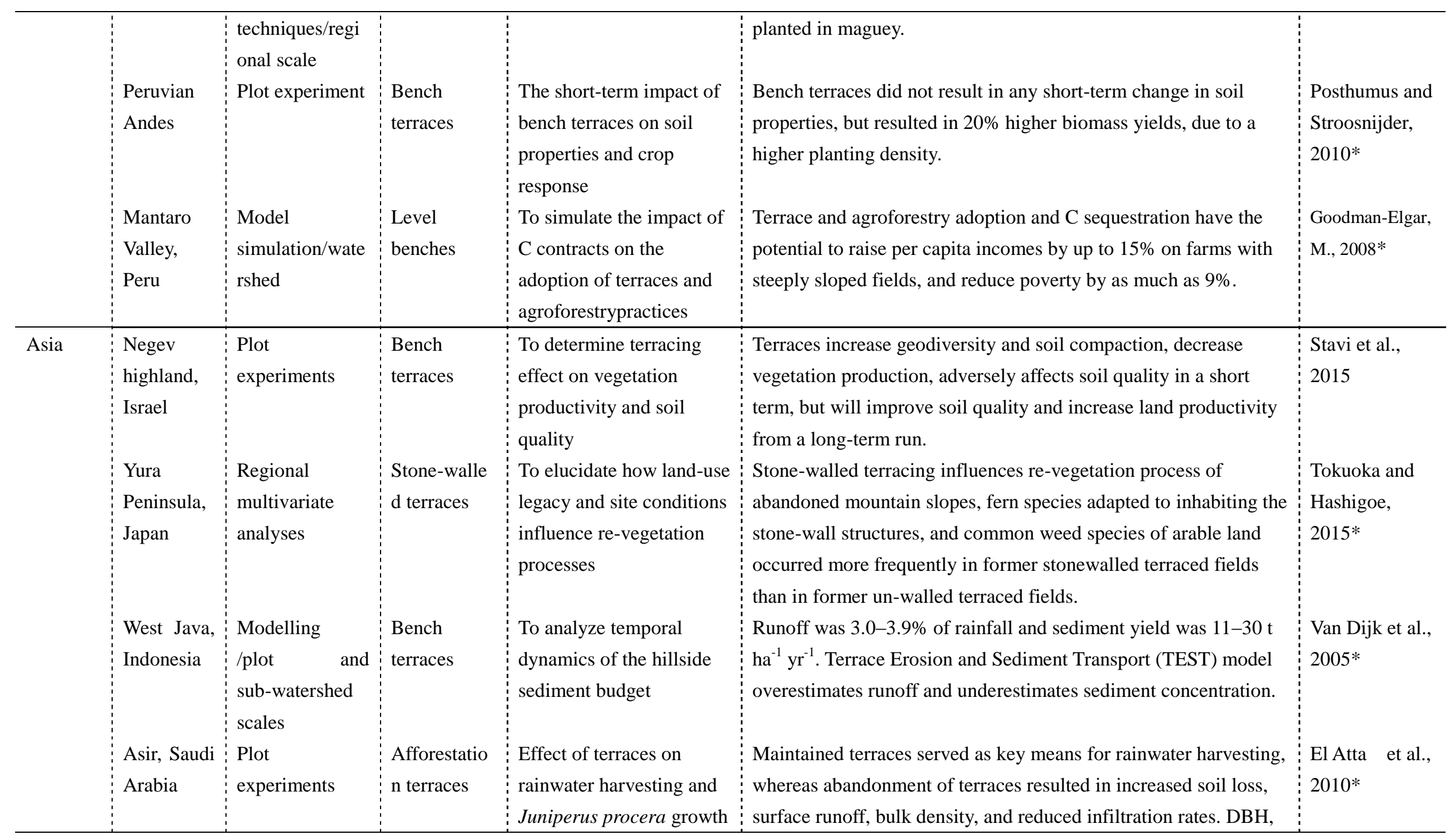




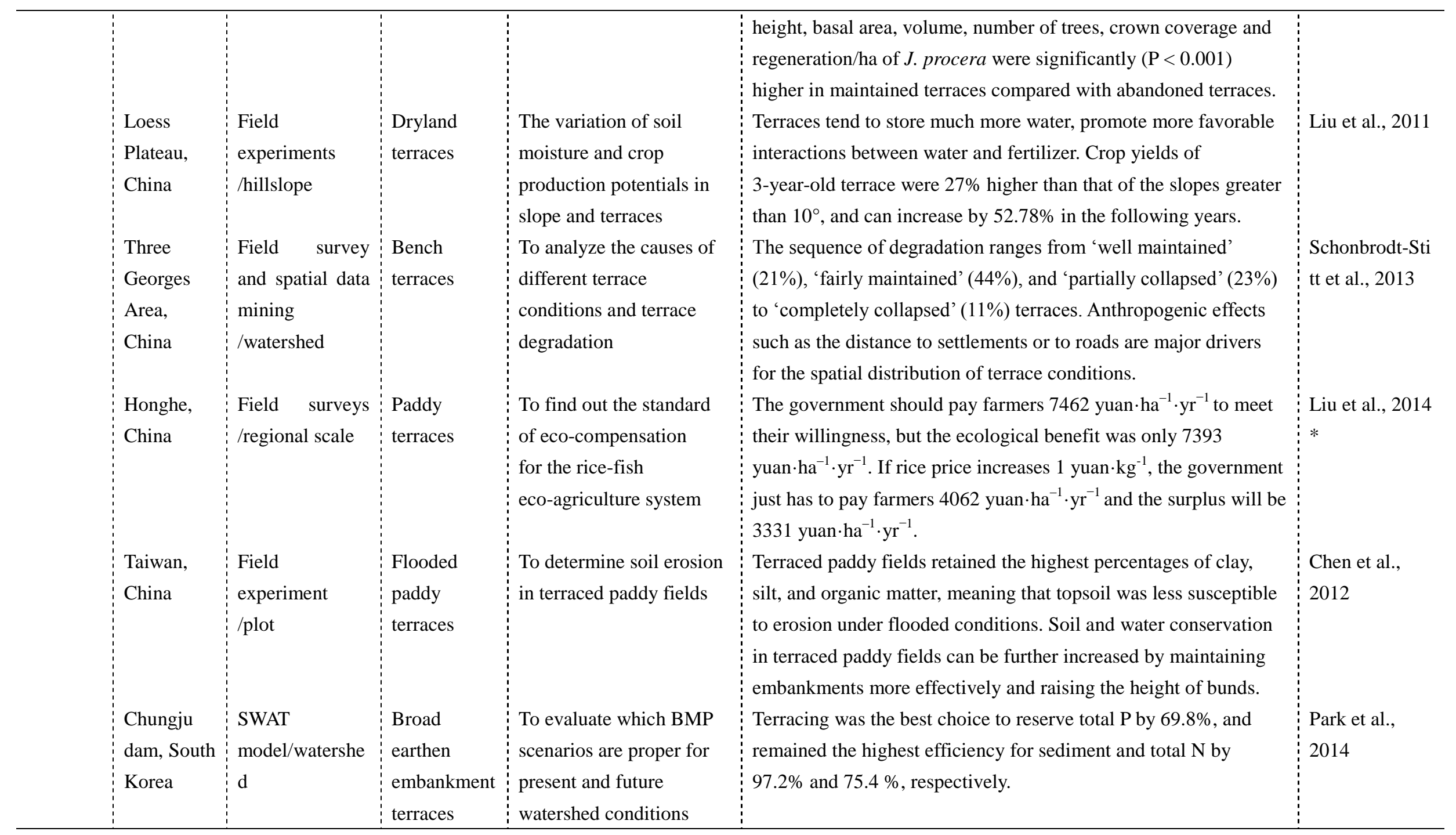




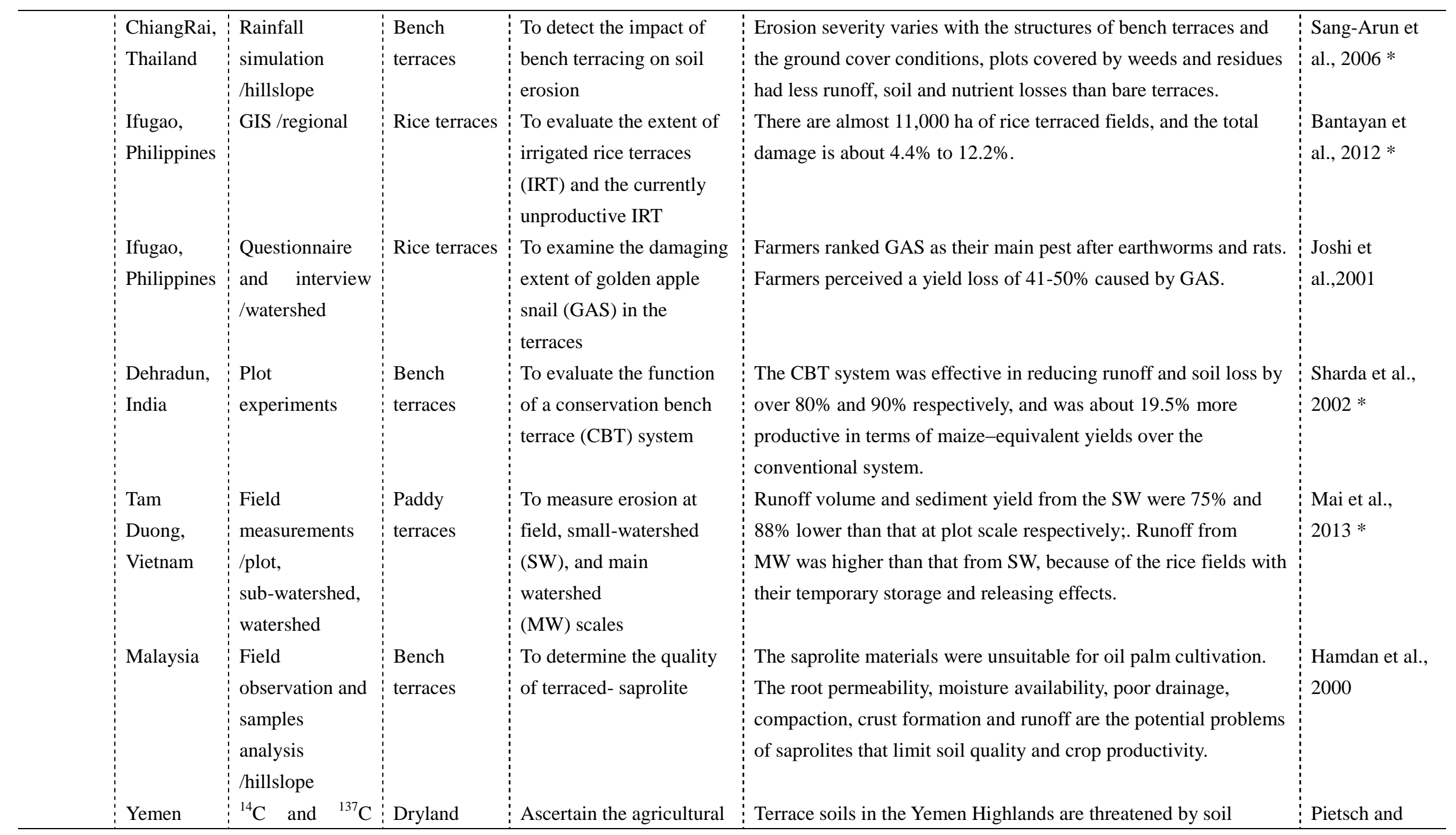




\begin{tabular}{|c|c|c|c|c|c|}
\hline Highlands & $\begin{array}{l}\text { isotope } \\
\text { /watershed }\end{array}$ & terraces & $\begin{array}{l}\text { suitability and } \\
\text { vulnerability to } \\
\text { degradation of terracing } \\
\text { systems }\end{array}$ & $\begin{array}{l}\text { erosion, but they are still agriculturally suitable, whatever they are } \\
\text { ancient terraced soils, eroded or cultivated modern soils. }\end{array}$ & Mabit, $2012 *$ \\
\hline $\begin{array}{l}\text { Dhading, } \\
\text { Nepal }\end{array}$ & $\begin{array}{l}\text { Field } \\
\text { monitoring/ plot }\end{array}$ & $\begin{array}{l}\text { Outward } \\
\text { sloping } \\
\text { agricultural } \\
\text { terraces }\end{array}$ & $\begin{array}{l}\text { To analyze the efficacy of } \\
\text { reduced tillage and crop } \\
\text { pattern on soil } \\
\text { conservation }\end{array}$ & $\begin{array}{l}\text { Soil loss from agricultural terraced land }\left(1.3 \mathrm{Mg} \mathrm{ha}^{-1} \mathrm{yr}^{-1}\right) \text { was } \\
\text { higher than that in forested terraces }\left(0.3 \mathrm{Mg} \mathrm{ha}^{-1} \mathrm{yr}^{-1}\right) \text {, while } \\
\text { reduced tillage can decrease runoff by } 11 \% \text { and soil loss by } 28 \% \text {. }\end{array}$ & $\begin{array}{l}\text { Tiwari et al., } \\
2009\end{array}$ \\
\hline $\begin{array}{l}\text { Jabal } \\
\text { Akhdar, } \\
\text { Oman }\end{array}$ & $\begin{array}{l}\text { Tracer } \\
\text { experiment } \\
(\mathrm{KBr}) / \text { hillslope }\end{array}$ & $\begin{array}{l}\text { Dryland } \\
\text { terraces }\end{array}$ & $\begin{array}{l}\text { To examine how terrace } \\
\text { structure and water } \\
\text { management maintain } \\
\text { agricultural productivity } \\
\text { and soil quality }\end{array}$ & $\begin{array}{l}\text { High quality irrigation water, the elaborately built soil structure of } \\
\text { the terraces, a system of water distribution designed to match crop } \\
\text { needs during their different growth stages and adequate drainage } \\
\text { are the main factors explaining the lack of salinization in ancient } \\
\text { mountain oases of Oman. }\end{array}$ & $\begin{array}{l}\text { Luedeling et } \\
\text { al., } 2005 *\end{array}$ \\
\hline $\begin{array}{l}\text { Petra, } \\
\text { Jordan }\end{array}$ & $\begin{array}{l}\text { Radiocarbon } \\
\text { dating } \\
\text { techniques/hillsl } \\
\text { ope }\end{array}$ & $\begin{array}{l}\text { Agricultural } \\
\text { terraces }\end{array}$ & $\begin{array}{l}\text { To determine the phases } \\
\text { of the construction, use } \\
\text { and abandonment of the } \\
\text { terraces }\end{array}$ & $\begin{array}{l}\text { Runoff terrace systems in the Petra region started around the } \\
\text { beginning of the Common Era, while construction, use and } \\
\text { maintenance lasted at least until } 800 \text { AD. }\end{array}$ & $\begin{array}{l}\text { Beckers et al., } \\
2013 *\end{array}$ \\
\hline Palestine & $\begin{array}{l}\text { Field } \\
\text { experiment and } \\
\text { questionnaire/ } \\
\text { watershed }\end{array}$ & $\begin{array}{l}\text { Stonewall } \\
\text { terraces }\end{array}$ & $\begin{array}{l}\text { To study the } \\
\text { socioeconomic impacts } \\
\text { of soil erosion on local } \\
\text { farmers and their } \\
\text { adoption of terracing }\end{array}$ & $\begin{array}{l}\text { Those areas with terracing practices had 3.5-6 times higher of net } \\
\text { profits than the areas without terracing. Farmers' incentives and } \\
\text { willingness to adopt terraces were highly affected by the } \\
\text { perceptions, land ownership, and geomorphology. }\end{array}$ & $\begin{array}{l}\text { Abu Hammad } \\
\text { and Borresen, } \\
2006\end{array}$ \\
\hline $\begin{array}{l}\text { the Gareh } \\
\text { Bygone } \\
\text { Plain, Iran }\end{array}$ & $\begin{array}{l}\text { Modelling/wate } \\
\text { rshed }\end{array}$ & $\begin{array}{l}\text { Level } \\
\text { ditches }\end{array}$ & $\begin{array}{l}\text { To analyze groundwater } \\
\text { recharge and the } \\
\text { increased crop } \\
\text { transpiration on terraces }\end{array}$ & $\begin{array}{l}\text { Groundwater recharge on the terrace increased on average by } \\
\text { four-fold. In a dry year, } 27 \% \text { of the infiltrated rain and floodwater } \\
\text { percolates on average to the aquifer and the recharge increases up } \\
\text { to } 69 \% \text { in a humid year. Without ditches, the transpiration rate of }\end{array}$ & $\begin{array}{l}\text { Raes et al., } \\
2008\end{array}$ \\
\hline
\end{tabular}




\begin{tabular}{|c|c|c|c|c|c|c|}
\hline & $\begin{array}{l}\text { Guilan, } \\
\text { Iran }\end{array}$ & $\begin{array}{l}\text { Samples } \\
\text { analysis/ slope }\end{array}$ & $\begin{array}{l}\text { Level } \\
\text { benches, } \\
\text { paddy } \\
\text { terraces }\end{array}$ & $\begin{array}{l}\text { To evaluate the impacts } \\
\text { of land leveling on soil } \\
\text { properties }\end{array}$ & $\begin{array}{l}\text { crops and biomass production were seriously limited. } \\
\text { Compared to traditional sites, land leveling had negative effects } \\
\text { on soil properties: increased soil bulk density by about } 20 \% \text {, and } \\
\text { reduced the number and species diversity of bacteria, fungi, } \\
\text { actinomycetes, and nematodes in the soils. }\end{array}$ & $\begin{array}{l}\text { Sharifi et al., } \\
2014\end{array}$ \\
\hline \multirow[t]{6}{*}{ Africa } & $\begin{array}{l}\text { Amrich } \\
\text { jessr, } \\
\text { Tunisia }\end{array}$ & $\begin{array}{l}\text { Rainfall } \\
\text { simulation/micr } \\
\text { o-catchment }\end{array}$ & $\begin{array}{l}\text { Dryland } \\
\text { terraces }\end{array}$ & $\begin{array}{l}\text { To examine the impact of } \\
\text { terraces on water } \\
\text { availability for crop } \\
\text { production }\end{array}$ & $\begin{array}{l}\text { The ratio "impluvium area/terrace area" (CCR) should be at least } \\
7.4 \text { in order to provide sufficient water for olive cultivation, } \\
\text { taking into account an average annual precipitation of } 235 \mathrm{~mm} \text {. }\end{array}$ & $\begin{array}{l}\text { Schiettecatte et } \\
\text { al., } 2005\end{array}$ \\
\hline & $\begin{array}{l}\text { Lushoto, } \\
\text { Tanzania }\end{array}$ & Plot experiment & $\begin{array}{l}\text { Bench } \\
\text { terraces }\end{array}$ & $\begin{array}{l}\text { Impact of Sustainable } \\
\text { Land Management (SLM) } \\
\text { measures on soil } \\
\text { degradation and crop } \\
\text { productivity }\end{array}$ & $\begin{array}{l}\text { SLM stabilized slope and reduced soil losses by erosion. } \\
\text { The use of high amounts of farmyard manure }\left(>6.0 \text { ton } \mathrm{ha}^{-1} \mathrm{y}^{-1}\right) \\
\text { on terraces resulted in an up to } 4 \text { times and } 7 \text { times higher yields } \\
\text { of maize and beans, respectively. }\end{array}$ & $\begin{array}{l}\text { Wickama et } \\
\text { al., } 2014\end{array}$ \\
\hline & $\begin{array}{l}\text { Taroudannt } \\
\text { Morocco }\end{array}$ & $\begin{array}{l}\text { Rainfall } \\
\text { simulation /plot }\end{array}$ & $\begin{array}{l}\text { Bench } \\
\text { terraces }\end{array}$ & $\begin{array}{l}\text { The influence of land } \\
\text { leveling on infiltration } \\
\text { rates }\end{array}$ & $\begin{array}{l}\text { Infiltration rates were very low on terraces due to the soils are } \\
\text { sealed by crusting. }\end{array}$ & $\begin{array}{l}\text { Peter and Ries, } \\
2013\end{array}$ \\
\hline & $\begin{array}{l}\text { Wello, } \\
\text { Ethiopia }\end{array}$ & Plot experiment & $\begin{array}{l}\text { Stone wall } \\
\text { Bench } \\
\text { terraces }\end{array}$ & $\begin{array}{l}\text { The role of farmland } \\
\text { terracing in maintaining } \\
\text { soil fertility }\end{array}$ & $\begin{array}{l}\text { Farmland terracing contributes greatly to the reduction of soil } \\
\text { erosion and nutrient loss, reduced fertility gradient between } \\
\text { erosion and deposition zone across the terrain. }\end{array}$ & $\begin{array}{l}\text { Shimeles et al., } \\
2012\end{array}$ \\
\hline & $\begin{array}{l}\text { Tigray, } \\
\text { Ethiopia }\end{array}$ & Plot experiment & $\begin{array}{l}\text { Stone wall } \\
\text { terraces, } \\
\text { bench } \\
\text { terraces }\end{array}$ & $\begin{array}{l}\text { To evaluate the } \\
\text { effectiveness of soil } \\
\text { conservation measures }\end{array}$ & $\begin{array}{l}\text { After terracing, sediment yield was reduced from } 14.3 \mathrm{t} \mathrm{ha}^{-1} \mathrm{y}^{-1} \text { to } \\
9 \mathrm{t} \mathrm{ha}^{-1} \mathrm{yr}^{-1} \text {, and the deposition of sediment increased from } 5.8 \mathrm{t} \\
\mathrm{ha}^{-1} \mathrm{yr}^{-1} \text { to } 7 \cdot 1 \mathrm{t} \mathrm{ha}^{-1} \mathrm{yr}^{-1} \text {. }\end{array}$ & $\begin{array}{l}\text { Nyssen et al., } \\
2009\end{array}$ \\
\hline & $\begin{array}{l}\text { Amhara, } \\
\text { Ethiopia }\end{array}$ & $\begin{array}{l}\text { Data collection, } \\
\text { field }\end{array}$ & $\begin{array}{l}\text { Stone wall } \\
\text { terraces }\end{array}$ & $\begin{array}{l}\text { To quantify terraces and } \\
\text { other soil conservation }\end{array}$ & $\begin{array}{l}\text { In terraces, the average yields of teff, barley and maize were } 0.95 \\
\left.\left.\mathrm{t} \mathrm{ha}^{-1} \text { (control } 0.49\right), 1.86 \mathrm{t} \mathrm{ha}^{-1} \text { (control } 0.61\right) \text {, and } 1.73 \mathrm{tha}^{-1}\end{array}$ & $\begin{array}{l}\text { Adgo et al., } \\
2013\end{array}$ \\
\hline
\end{tabular}




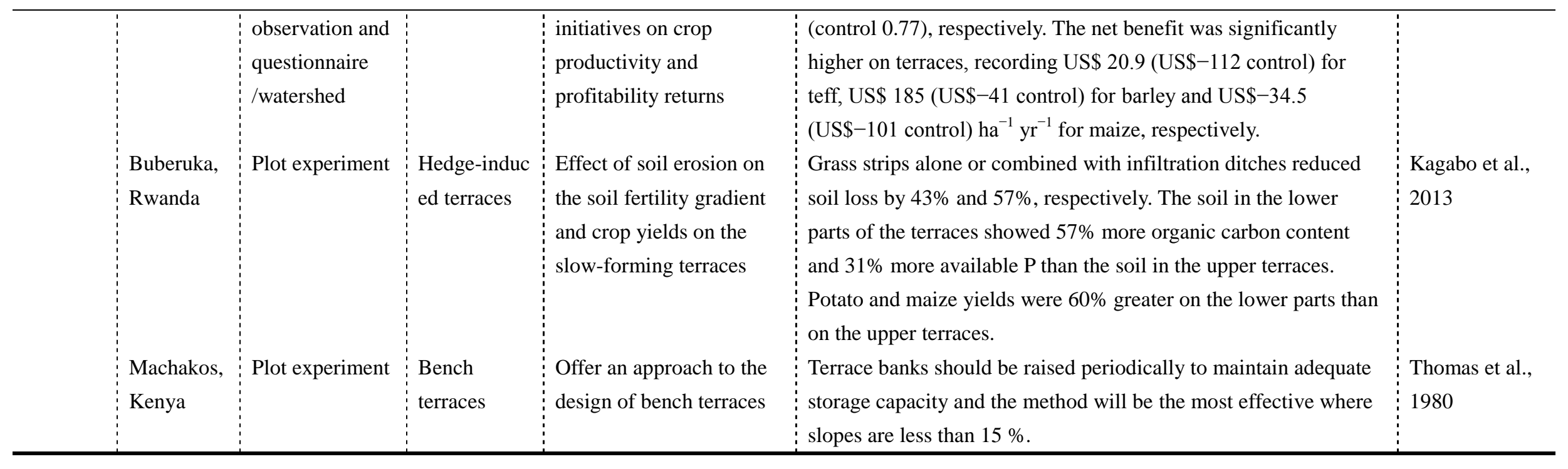

Note: the cited literature with $*$ represents ancient terraces, while others without $*$ refer to modern terrace cases. 
Table 3 Descriptive $\delta$ features of terracing by collected case studies.

\begin{tabular}{lllllllll}
\hline$\delta$ & Range & Minimum & Maximum & Sum & Mean & Variance & C.V. & N \\
\hline$\delta_{r r}$ & 45.25 & 0.02 & 45.27 & 273.16 & 2.60 & 21.68 & 1.79 & 105 \\
$\delta_{s m}$ & 5.52 & 0.70 & 6.22 & 269.34 & 1.20 & 0.33 & 0.48 & 225 \\
$\delta_{s e}$ & 275.86 & 0.14 & 276 & 1764.17 & 11.46 & 719.71 & 2.34 & 154 \\
$\delta_{s n}$ & 1.70 & 0.80 & 2.50 & 129.81 & 1.20 & 0.08 & 0.23 & 108 \\
$\delta_{b m}$ & 6.15 & 0.69 & 6.83 & 147.44 & 1.94 & 719.71 & 0.59 & 76 \\
\hline
\end{tabular}


Table 4 Example of terracing costs (Based on Yang et al., 2014).

\begin{tabular}{ccccccc}
\hline \multirow{2}{*}{$\left(^{\circ}\right)$} & TTW & Earthwork & \multicolumn{4}{c}{ Terracing costs (US\$/ha) } \\
\cline { 5 - 6 } & $(\mathrm{m})$ & $\left(\mathrm{m}^{3} / \mathrm{ha}\right)$ & MC & AC & SEC & Total \\
\hline $\mathbf{5}$ & 14 & 1613 & 1209 & 387 & 322 & 1918 \\
$\mathbf{1 0}$ & 10 & 2454 & 1491 & 483 & 475 & 2450 \\
$\mathbf{1 5}$ & 8 & 3170 & 1773 & 580 & 629 & 2981 \\
$\mathbf{2 0}$ & 6 & 3456 & 2055 & 677 & 782 & 3513 \\
$\mathbf{2 5}$ & 4 & 3191 & 2337 & 774 & 935 & 4045 \\
\hline
\end{tabular}

Note: OTSG, TTW, TBH, MC, AC and SEC refer to original terrain slope gradient, terrace trend width, the economic cost by mechanization, economic cost by manpower and labor, and socioeconomic cost, respectively. 

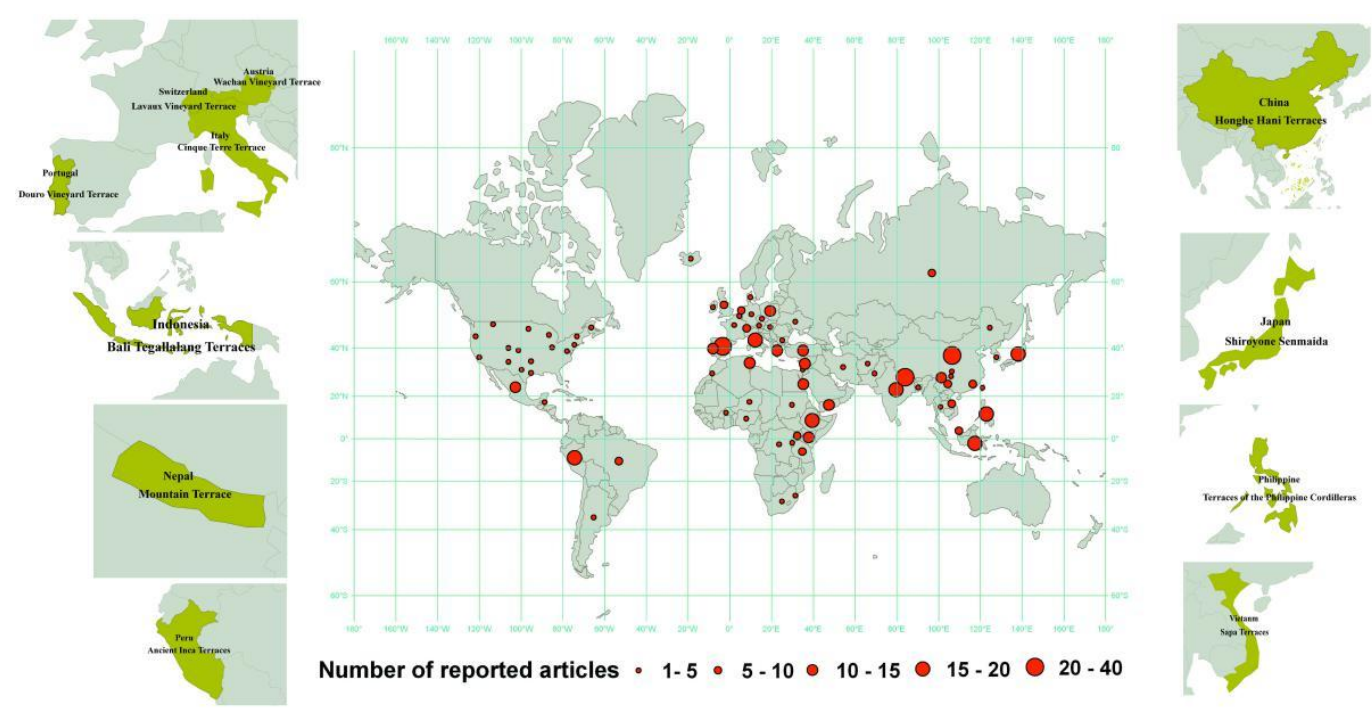

Figure 1 Worldwide distribution of terracing.

(Note: The most representative ancient terraces across the globe were especially extracted in both left and right sides of the figure, based on the World Heritage List of UNESCO (United Nations Educational, Scientific and Cultural Organization) and GIAHS (Globally Important Agricultural Heritage Systems) as well as some other important historical terraces recorded in literature. They were used for distinguishing ancient terracing practices from modern terraces.) 

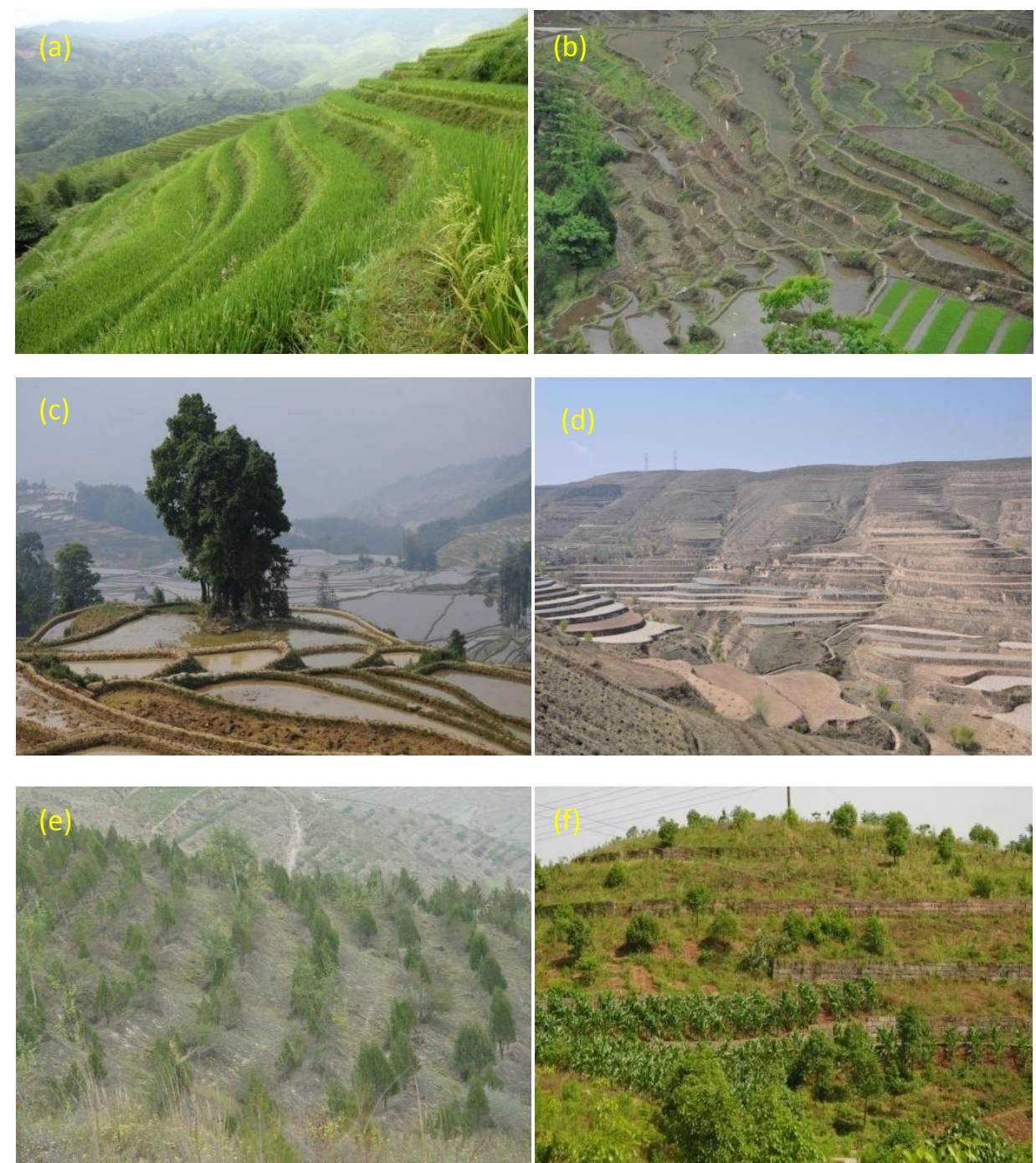

Figure 2 Examples of diverse terracing types.

(Note: Terracing can be classified in different ways due to its diversity in practice. Taking China as an example: (a) Paddy Longji Bench Terraces; (b) Paddy Terraces in union county of Fujian; (c) Hani Heritage Terraced Landscape; (d) Dryland broad-based terraces in the Loess Plateau for agricultural production and (e) Zig terraces for ecosystem restoration with planted arborvitae; (f) Sloping terraces in Chongqing: brick-wall construction for vegetation restoration in the upper hillslope and for crops in the lower position of hillslope.) 

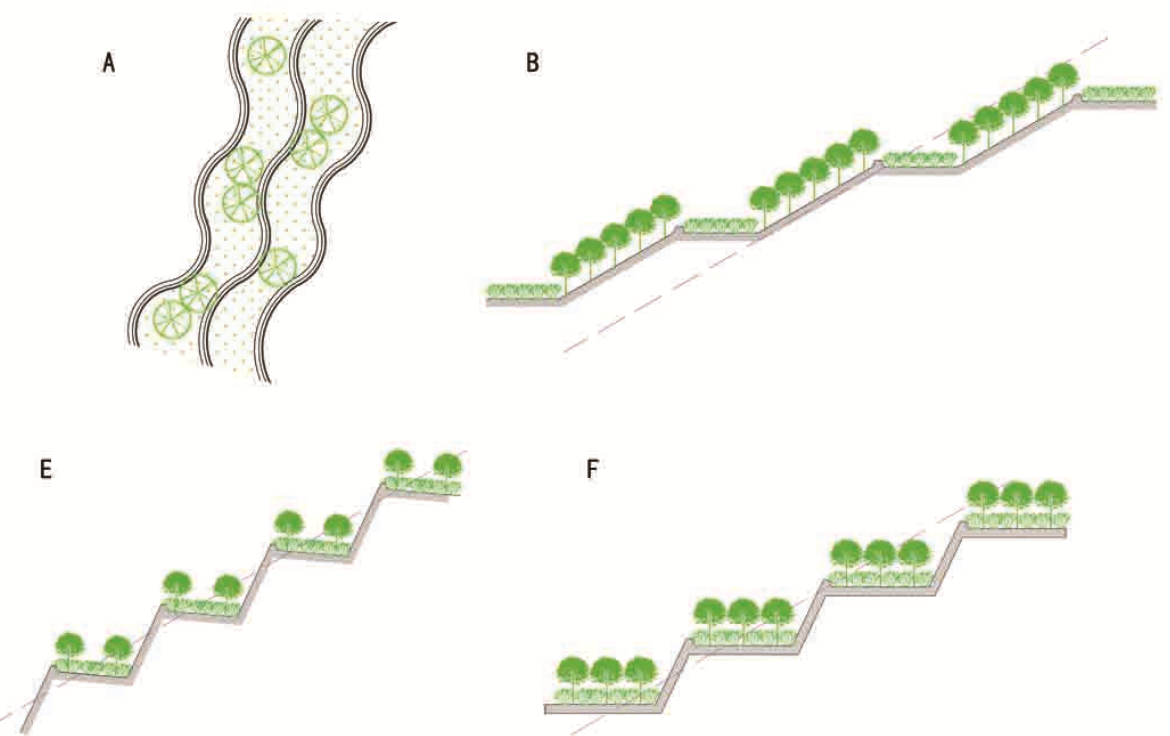

c

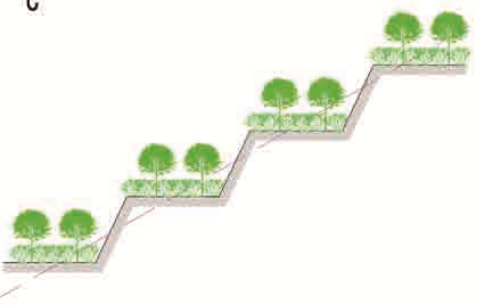

G

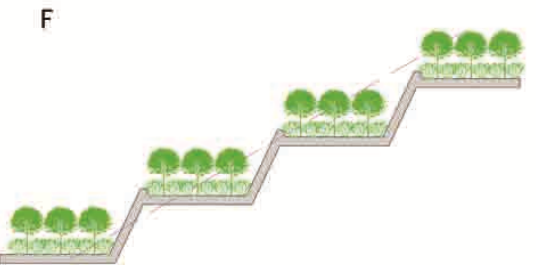<smiles>C1=C[C@H]2CC[C+]1C2</smiles>

9000

$\sin 0$

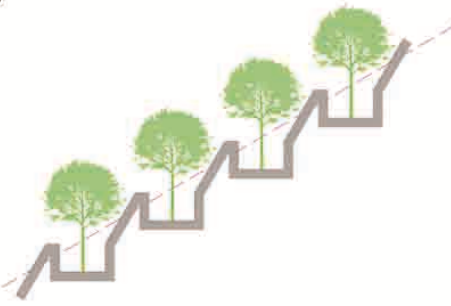

H

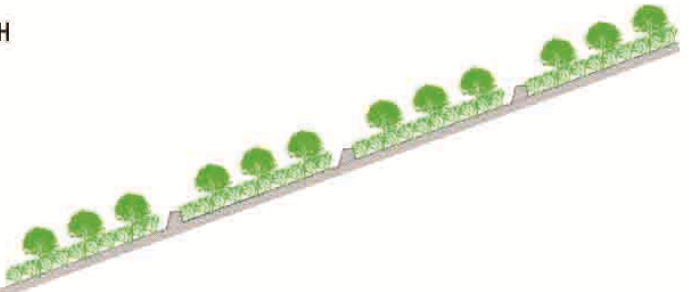

Figure 3 Some typical terracing types based on the differences in structure and appearance

(Note: A: wave-like terraces; B: slope separated terraces; C: level benches/level terraces without embankments; D: level ditches; E: zig terraces; F: broad-based terraces with embankments; G: half-moon terraces / fish-scale pits; H: natural slope) 

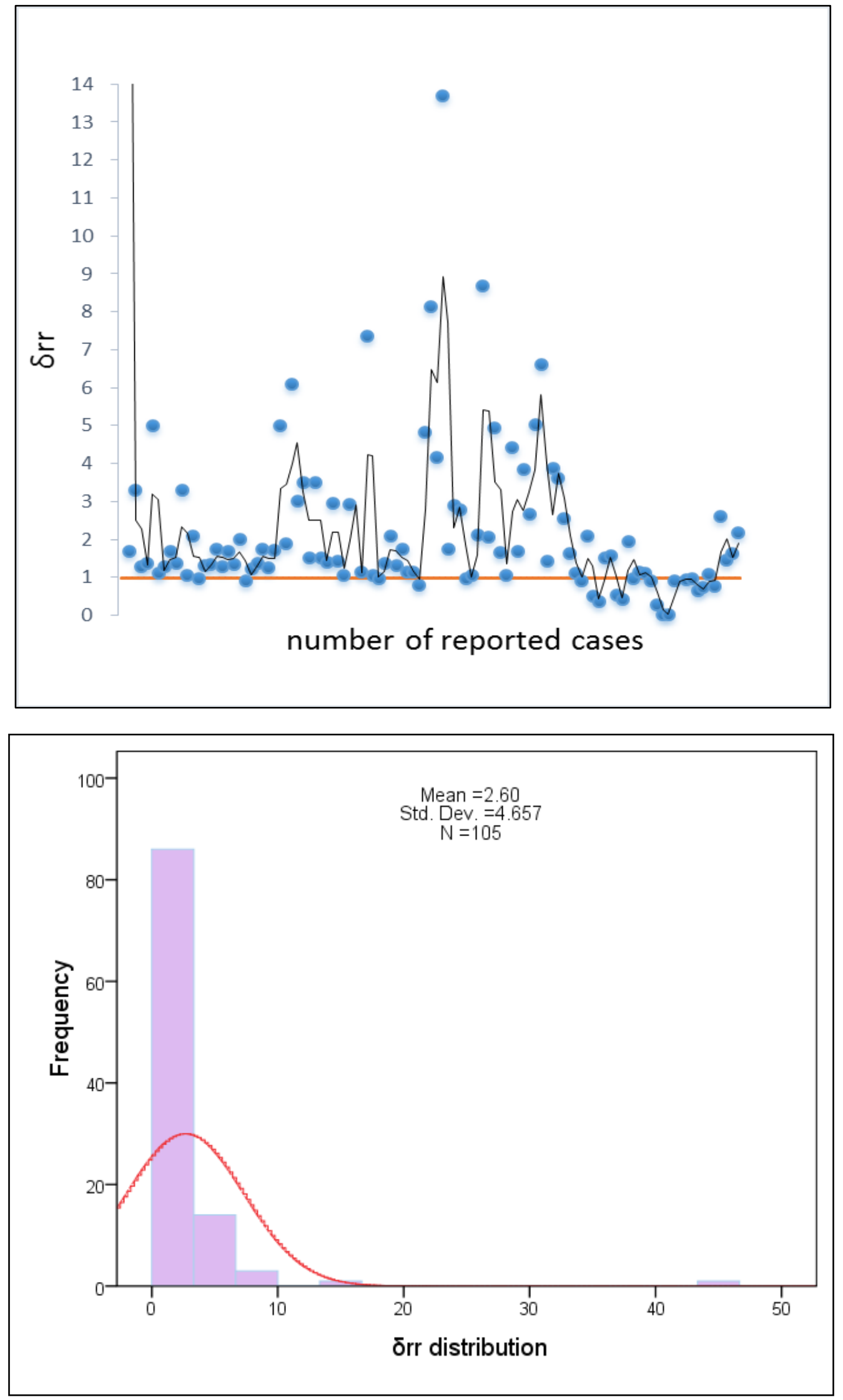

Figure 4 The terracing efficiency on runoff reduction. 

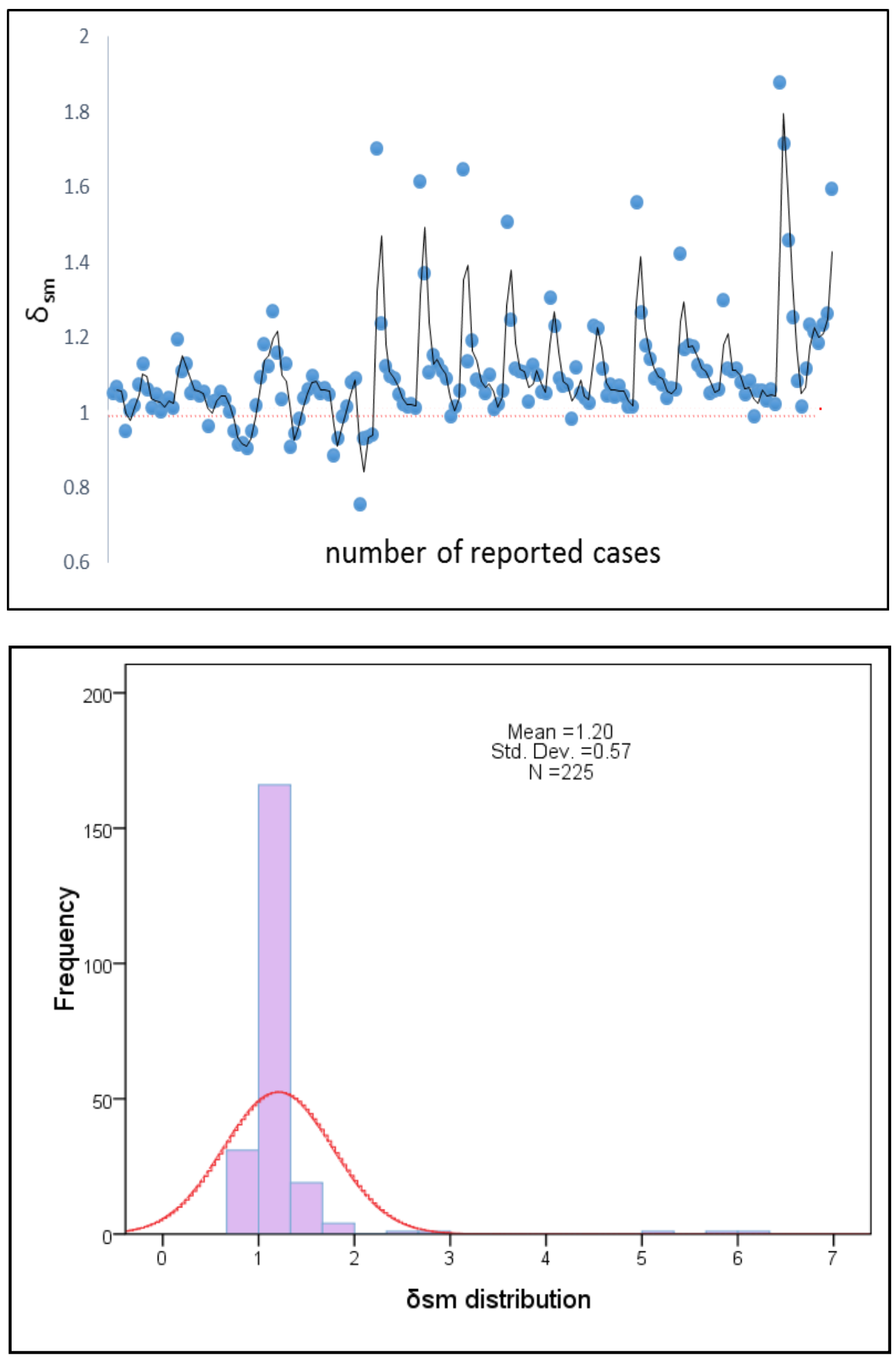

Figure 5 The terracing efficiency on soil water recharge. 

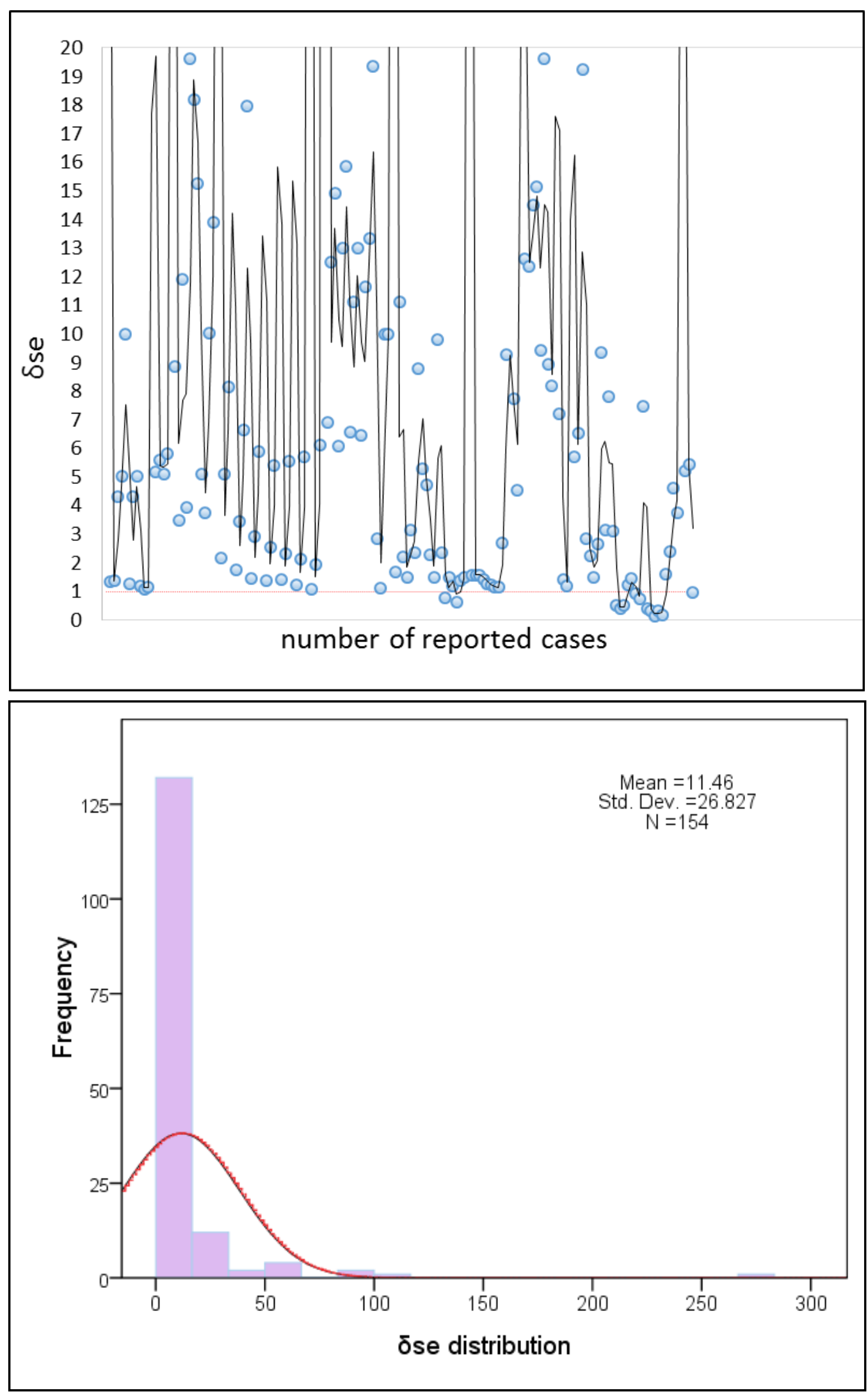

Figure 6 The terracing efficiency on erosion control and soil conservation. 

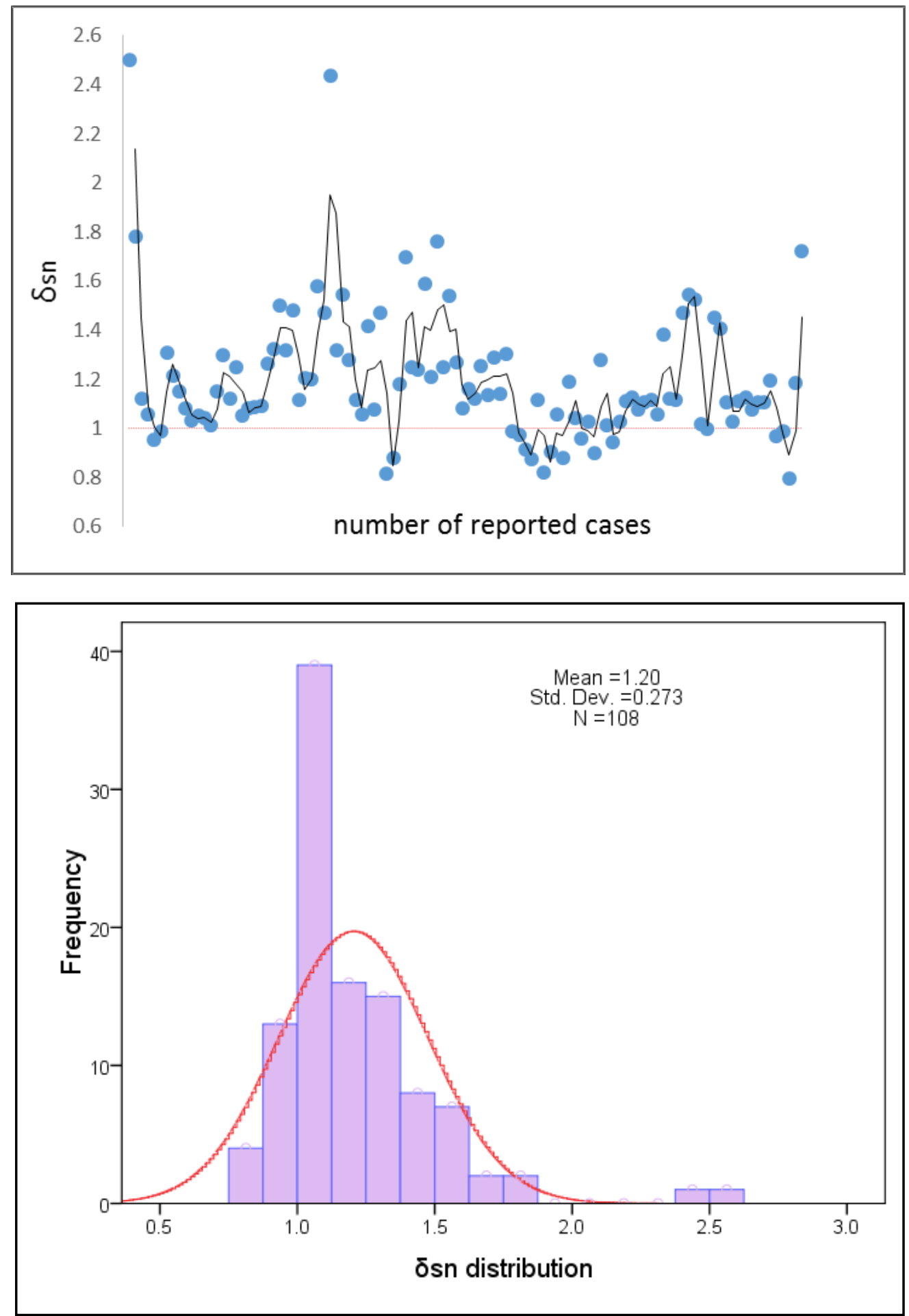

Figure 7 The terracing efficiency on soil nutrients and land productivity. 

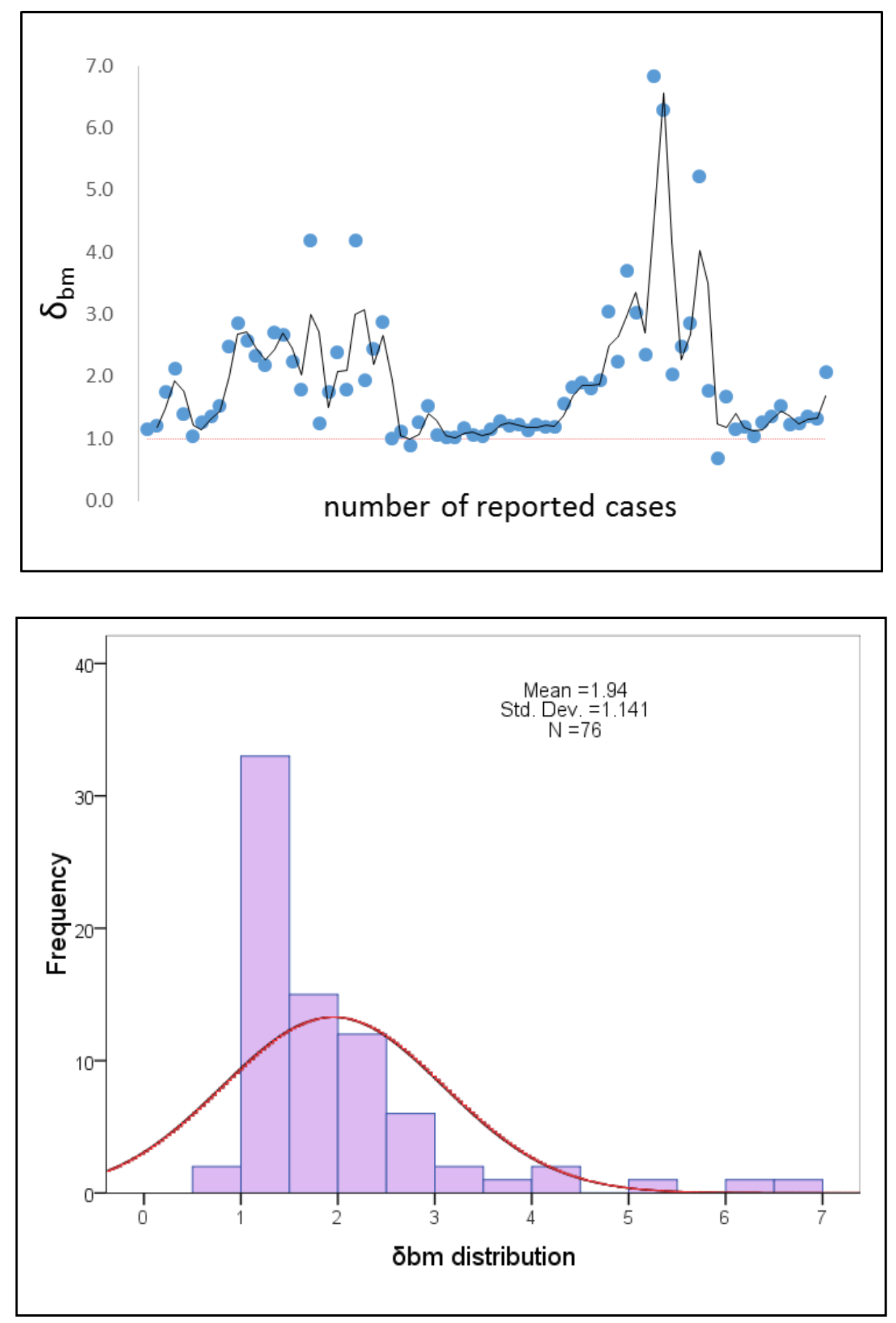

Figure 8 The terracing efficiency on crop yields and biomass accumulation. 


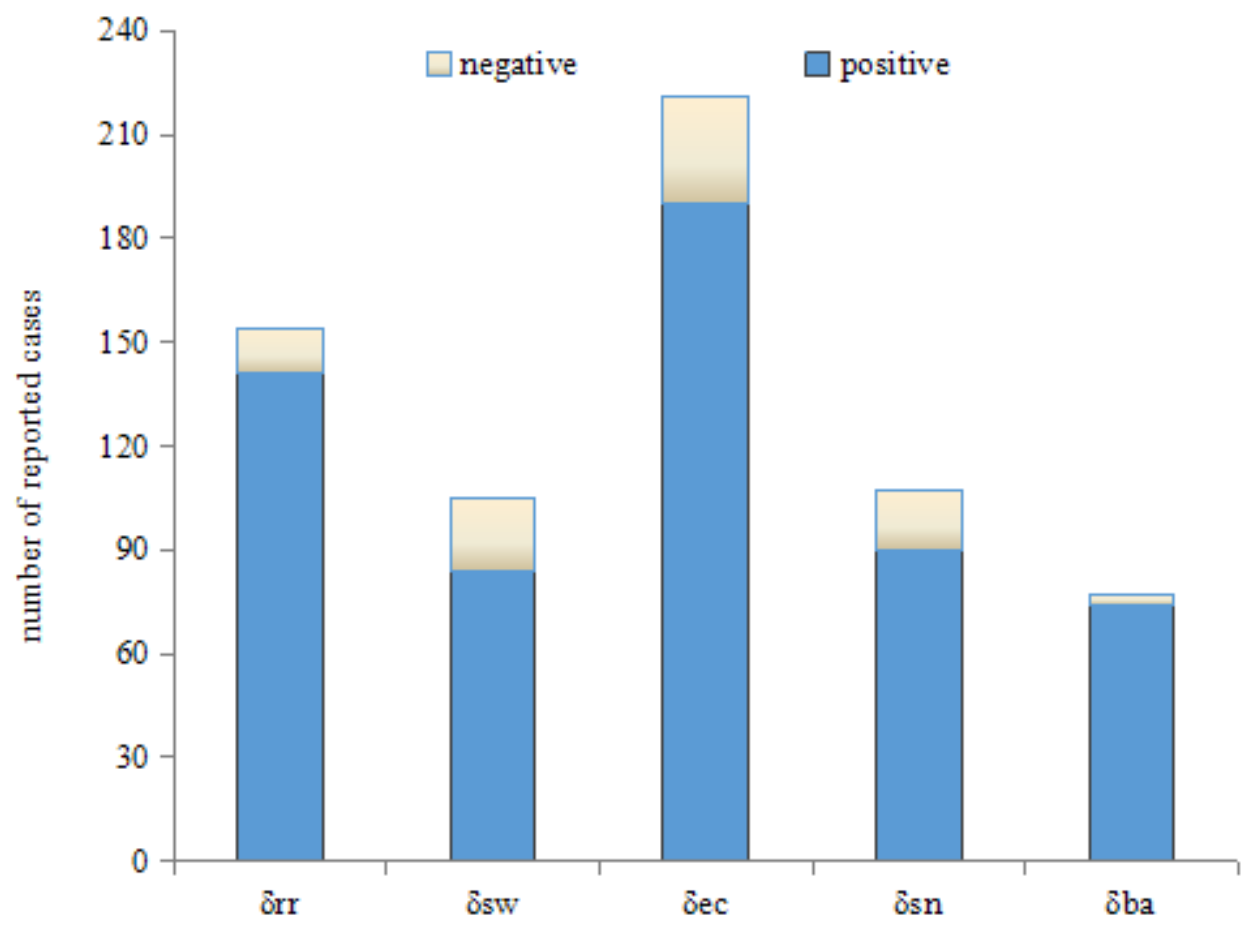

Figure 9 Number of reports on the negative and positive effects of terracing. 


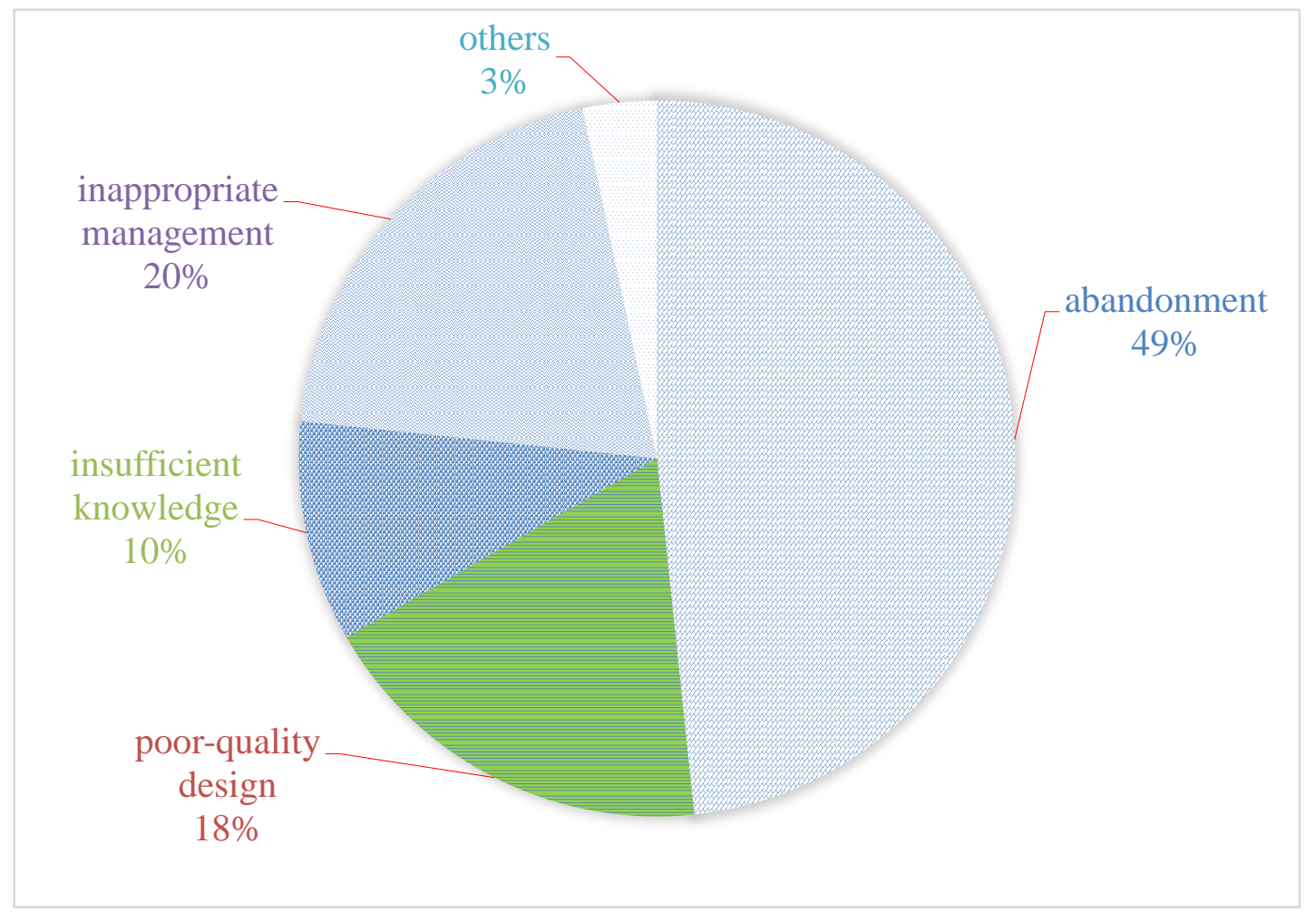

Figure 10 Major reasons responsible for the negative effects of terracing. 